\title{
Chapter 4. Competing controllers and agreement potential
}

Marina Chumakina \& Oliver Bond

University of Surrey

CHAPTER 4. COMPETING CONTROLLERS AND AGREEMENT POTENTIAL 1

4.1 INTRODUCTION 2

4.2 TYPICAL AND ATYPICAL CONTROLLERS

4.2.1 CONJOINED PHRASES

4.2.2 NUMERAL PHRASES

4.3 COMPETING CONTROLLERS: BIABSOLUTIVE CONSTRUCTIONS

4.3.1 SEMANTICS OF THE BIABSOLUTIVE CONSTRUCTION

4.3.2 NON-VERBAL TARGETS IN BIABSOLUTIVE CONSTRUCTIONS

4.3.3 THE SYNTACTIC STATUS OF ABSOLUTIVE OBJECTS

4.4 AGREEMENT POTENTIAL $\quad \mathbf{3 5}$

4.4.1 AGREEING VS. NON-AGREEING VERBS 36

4.4.2 AGREEING VS. NON-AGREEING ADVERBS

$\begin{array}{ll}\text { 4.4.3 AGREEING VS. NON-AGREEING POSTPOSITIONS } & 38\end{array}$

4.4.4 AGREEING VS. NON-AGREEING MODIFIERS $\quad 39$

$\begin{array}{lr}4.5 \text { CONCLUSION } & 41\end{array}$

\section{TABLES}

TABLE 4.1. LEXICAL ITEMS WITH AGREEMENT POTENTIAL, BASED ON DATA FROM THE ARCHI DICTIONARY,

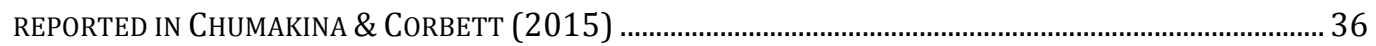

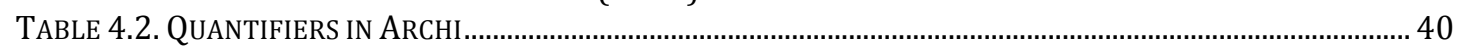




\subsection{Introduction}

An adequate theory of syntax must be flexible enough to accommodate and account for non-uniformity within an agreement system. Archi provides a rich testing ground for the types of issues a model must incorporate, since its agreement system exhibits a range of non-canonical behaviour (Corbett 2006). This is most clearly encountered when the presence of an atypical controller within a given syntactic construction is responsible for a deviation from a canonical agreement relation.

In the most straightforward, canonical cases, agreement in Archi is syntactic in nature. Syntactic agreement (sometimes called 'agreement ad formam', 'formal agreement' or 'grammatical agreement') is agreement consistent with the formal properties of the controller (Corbett 2006: 155). For instance, in the sentence the committee leaves at $3 p m$ agreement on the verb is determined by the thirdperson singular feature specification of the controller. In English, then, the morphosyntactic features relevant for syntactic agreement are NUMBER and PERSON; in Archi the principal agreement features are GENDER and NUMBER, with PERSON relevant to a lesser extent (see Corbett 2012: 239-251 for discussion).

Semantic agreement (also known as 'agreement ad sensum', 'notional agreement', 'logical agreement' or 'synesis') is agreement consistent with a semantic aspect of a controller's meaning rather than its formal properties (Corbett 2006: 155). In the sentence 'the committee leave at 3pm' the property of the controller that is relevant for agreement is that a plurality of individuals make up the committee. Usually, semantics and syntax come together such that agreement is concurrently syntactic and semantic in nature.

A number of atypical controllers are known to be capable of triggering semantic rather than syntactic agreement $(\S 4.2)$. Coordinated noun phrase controllers are well known for exhibiting the potential for this type of non-canonical behaviour (Corbett 2006: 168). Coordinated noun phrase controllers are of interest in determining the properties of an adequate syntactic model because their agreement targets may exhibit variation in terms of which co-head in a coordinated noun phrase has the potential to control agreement. In Archi, coordinated absolutive controllers can trigger agreement with semantic rather than syntactic properties of their controller (§4.2.1). For instance, when singular nouns are coordinated, the predicate may be treated as plural for the purposes of agreement. When nouns with different genders are coordinated, different resolution rules are required to account for the patterns of gender agreement in the clause. In a strictly syntactic account, agreement would be consistently controlled by only one of the conjuncts.

Another challenging issue emerges in modelling agreement with numeral phrases (§4.2.2). As with coordinated noun phrase controllers, absolutive arguments in which the lexical head of the phrase is quantified by a numeral exhibit potential for variation in the type of agreement relation they control within the clausal domain. Numerals in Archi impose a restriction on the head they modify in terms of its grammatical properties: the head noun must occur in 
the singular. Consequently, when grammatical features of numeral phrases control syntactic agreement, verbal targets appear in their singular form. However, plural semantic agreement with numerally modified nouns is also possible (§4.2.2). This type of non-uniformity gives rise to a situation in which agreement in the clausal domain may differ from agreement in the noun phrase in terms of the number value relevant for determining the form of targets.

A further instance of non-uniformity within the Archi agreement system is found in biabsolutive constructions (§4.3). While agreement within the clausal domain is normally controlled by the only absolutive argument of a clause (§3.3), the presence of two absolutive arguments within the biabsolutive construction poses a particularly challenging problem for models of syntax $(\S 4.3)$, because there is more than one possible candidate for the agreement controller. This is reflected by the fact that in biabsolutive constructions individual component parts of a periphrastic verb can agree with different controllers - namely the absolutive subject and the absolutive object of the clause.

Finally, we address the problems for theory introduced by differences in the agreement potential of items within a lexical class (\$4.4). While agreement is a pervasive property of Archi, found in nearly every major word class, this does not mean that every item with a given class can agree. For instance, only a third of verbs have agreement potential in Archi. This presents a challenge for theoretical approaches to parts of speech that anticipate uniformity as a normal characteristic of lexical classes.

\subsection{Typical and atypical controllers}

Atypical controllers of agreement present prospective problems for a theoretical account of agreement by introducing the potential for non-uniformity within the agreement system. While a canonical controller of agreement has a consistent and predictable set of morphosyntactic features that participate in an agreement relation, there are two types of non-canonical controllers in Archi that allow for a degree of variation in terms of which set of features are relevant in determining a target's inflectional exponence. Conjoined phrases, namely those in which two co-heads are syntactically coordinated, present the first challenge. When conjoined phrases consist of two or more heads with two (or more) sets of gender and/or number values, the agreement system is required to determine which set of features from which head to agree with (or indeed to resolve the problem in a completely different way). This type of coordinated noun phrase is discussed in $\S 4.2 .1$. The second type of atypical controller, examined in $\S 4.2 .2$, is also capable of triggering semantic (rather than syntactic) agreement. In such cases, the agreement target's number value has the potential to be determined by properties of the plural semantics of a controller modified by a numeral, rather than a more strictly determined set of syntactic features. 


\subsubsection{Conjoined phrases}

Conjoined noun phrases in Archi consist of (at least) two different syntactic coheads, which are juxtaposed within an NP structure. Each conjoined phrase acts as a host to an enclitic with the form $=w u /=u$. For instance, in (1) the subject

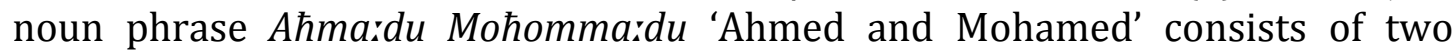
conjoined co-heads, each marked with the coordination clitic $=u$. Both coordinands share the same gender and number feature values, namely, they are each gender I singular. The form of the verb $b a q^{\varsigma} a$ 'came' in (1a) and the auxiliary ebtili 'became' in (1b) demonstrate that the combination of singular number features on the individual coordinands in a conjoined NP subject trigger plural agreement on viable targets. An alternative situation, in which the (functional) head of the predicate agrees with only one of the coordinands in number, is ungrammatical, as shown in (1c) for 'come' and 'become cold'.
(1)
a. Ahma: $d=u$
Moћomma:d=u
Ahmed(I)[SG.ABS] $=$ and Mohamed(I)[SG.ABS] $=$ and
'Ahmed and Mohamed came.'
ba-q $q^{\text {a }}$
I/II.PL-Come.PFV
b. $\quad A \hbar m a: d=u \quad$ Mohomma:d=u $\chi^{\varsigma}$ e e<b`tri-li
Ahmed(I)[SG.ABS]=and Mohamed(I)[SG.ABS] =and cold «I/II.PL〉become.PFV-EVID
'Ahmed and Mohamed got cold.'

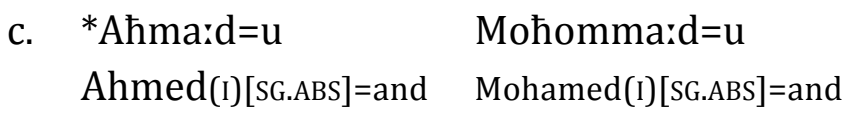
$\mathrm{q}^{\mathrm{w} \varsigma} \mathrm{a} / \chi^{\varsigma} \mathrm{e} \quad$ i<w>t:i-li
I.SG.come.PFV/cold «I.SG `become.PFV

Intended: 'Ahmed and Mohamed came/got cold.'

When an absolutive conjoined phrase consists of co-heads of different human genders, namely genders I and II, then the same situation holds, and the syncretic gender I/II plural form is used. For instance, in (2a) the gender mismatch between the two co-heads of the subject noun phrase is avoided by the use of I/II plural agreement inflection. It is not possible for the verb to agree with only one of the conjuncts, as demonstrated by the ungrammatical structures in (2b).
a. $\quad u s ̌ d u=w u$
došdur=u
ba-q $\mathrm{q}^{\varsigma} \mathrm{x} \chi^{\varsigma} \mathrm{e}$
$\mathrm{e}<\mathrm{b}>\mathrm{t}: \mathrm{i}$
brother(I)[SG.ABS]=and sister(II)[SG.ABS]=and I/II.PL-come.PFV/cold
«I/II.PL ১become.PFV
'Brother and sister came/got cold.'
b. *ušdu=wu došdur=u da-q $q^{\varsigma} a / \chi^{\varsigma}$ e $<$ rst:i
brother(I)[SG.ABS]=and sister(II)[SG.ABS]=and II.SG-come.PFV/cold 〈II.SG $>$ become.PFV
Intended: 'Brother and sister got came/got cold.'

Semantic agreement with coordinated noun phrases in Archi is preferred over syntactic agreement with a single conjunct independently of the word order in the clause (e.g. whether the clause is verb-initial or verb-final), the gender of the conjuncts and/or the semantic type of the predicate. For instance, in the transitive clause in (3a), the verb agrees with an absolutive argument consisting 
of conjoined phrase with two gender I singular co-heads. Here, gender I/II plural agreement on the head of the predicate is possible, as illustrated by $a b u$ 'do' in (3a). However, agreement with the syntactically closest conjunct only is not possible, as illustrated by the ungrammatical construction with the verb uw 'do' in $(3 b)$.

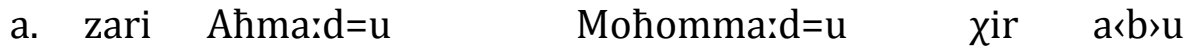 1SG.ERG Ahmed(I)[SG.ABS]=and Mohamed(I)[SG.ABS]=and behind «I/II.PL〉do.PFV 'I brought Ahmed and Mohamed.'

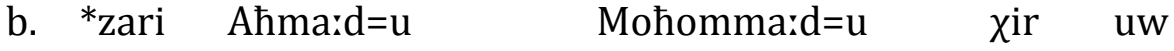 1SG.ERG Ahmed(I)[SG.ABS]=and Mohamed(I)[SG.ABS]=and behind I.SG.do.PFV Intended: 'I brought Ahmed and Mohamed.'

Similarly, in (4a), where the verb precedes the subject, the properties of the conjoined noun phrase, namely gender I/II plural, are relevant for the agreement relation, so the verb occurs in the form $b a q^{\varsigma} a$ 'come'. Agreement with the conjunct closest to the verb is not possible, as illustrated in (4b) where the verb $q^{w s} a$ 'come' agrees only in the number and gender of the conjunct $u s ̌ d u=w u$ brother'.
a. ba-q ${ }^{\varsigma} a$
ušdu=wu
došdur-u
I/II.PL-come.PFV
'Brother and sister came.'
brother(I) [SG.ABS] =and $\operatorname{sister}(\mathrm{II})[\mathrm{SG} . \mathrm{ABS}]=$ and
b. ${ }^{*} \mathrm{q}^{\mathrm{w} \varsigma} \mathrm{a} \quad \mathrm{ušdu}=\mathrm{wu} \quad$ došdur-u
I.SG.come.PFV brother(I)[SG.ABS]=and sister(II)[SG.ABS]=and
Intended: 'Brother and sister came.'

The same pattern is observed with animate nouns of gender III and IV. In (5a), the verb agrees semantically with the coordinated noun phrases, resulting in a plural form of the verb. Example (5b) shows that, just as with nouns of genders I and II, agreement with the closest conjunct to the verb is not grammatical.
(5)
a. motorl=u
gatu=wu
$\mathrm{q}^{\mathrm{\top}} \mathrm{a}$
goat.kid(IV)[SG.ABS]=and cat(III)[SG.ABS]=and [III/IV.PL]come.PFV
'A goat kid and a cat came.'
b. ${ }^{*}$ moto:l=u
gatu-wu
ba-q ${ }^{\varsigma} a$
goat.kid(IV)[SG.ABS]=and cat(III)[SG.ABS]=and III.SG-come.PFV
Intended: 'A goat kid and a cat came.'

Agreement with properties of the entire phrase, rather than properties of the closest conjunct, is maintained regardless of whether the verb is in initial or final position. The same situation prevails in (elicited) sentences even when the two coordinands share identical feature sets, as in (6), where both conjuncts are gender I singular. Once again, the combined features of the conjoined noun 
phrase control agreement as in (6a), and not the properties of a single coordinand, as in (6b).
a. ba-q ${ }^{\mathrm{s}} \mathrm{a}$
$A \hbar m a: d=u$
I/II.PL-come.PFV Ahmed(I)[SG.ABS]=and
'Ahmed and Mohamed came.'
Mohomma:d=u
Mohamed(I)[SG.ABS]=and
b. ${ }^{*} \mathrm{q}^{\mathrm{w}} \mathrm{a} \quad$ Ahma:d=u Mohomma:d=u
I.SG.come.PFV Ahmed(I)[SG.ABS]=and Mohamed(I)[SG.ABS]=and
Intended: 'Ahmed and Mohamed came.'

The examples in (7) show the same pattern with animate nouns of gender III.
a. $q^{\varsigma} a$
$\chi^{\varsigma} \mathrm{O}: \mathrm{n}=\mathrm{u}$
no: ${ }^{r} \mathrm{~s}=\mathrm{u}$
[III/IV.PL]come.PFV cow(III)[SG.ABS]=and horse(III)[SG.ABS]=and
'A cow and a horse came.'
b. *ba-q'a no: $\chi^{\varsigma} \check{s}^{\varsigma}=u$
III.SG-come.PFV cow(III) [SG.ABS]=and horse(III)[SG.ABS]=and
Intended: 'A cow and a horse came.'

With inanimates of gender III and IV the same semantic agreement pattern is seen. Again, agreement with the closest conjunct is ungrammatical, as shown by the contrast between (8a) and (8b).
(8)

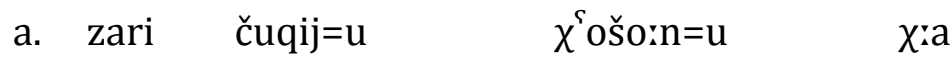
1SG.ERG $\operatorname{coat}(\mathrm{IV})[\mathrm{SG} . \mathrm{ABS}]=$ and $\operatorname{dress}(\mathrm{III})[\mathrm{SG} . \mathrm{ABS}]=$ and $[\mathrm{III} / \mathrm{IV} . \mathrm{PL}] \mathrm{bring.PFV}$
'I brought a coat and a dress.'
b. *zari čuqij=u $\quad \chi^{\varsigma}$ ošo:n $=u \quad$ ba- $\chi: a$
1SG.ERG coat(IV)[SG.ABS]=and dress(III)[SG.ABS]=and III.SG-bring.PFV
Intended: 'I brought a coat and a dress.'

In Archi, agreement with the closest conjunct is only allowed in elliptical structures in which the predicate associated with the second conjunct is presumed to be elided. This is illustrated by the contrast in (9). In (9a), the verb ert:ili 'become' agrees in gender and number with the preceding noun phrase, while the associated conjunct occurs in a post verbal position. A similar structure is possible in which the second conjunct is the subject of a non-elided predicate, as in $(9 b)$.
(9) a. došdur=u $\quad \chi^{\varsigma}$ e e $\ll r>t: i-l i \quad u s ̌ d u=w u$ sister(II)[SG.ABS]=and cold 〈II.SG〉become.PFV-EVID brother(I)[SG.ABS]=and 'Sister and brother got cold.'




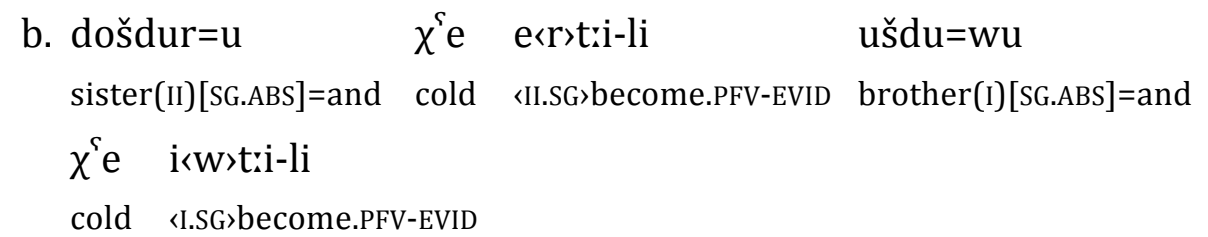

'Sister and brother got cold.'

Disjunctively conjoined arguments in Archi paint a different picture in which agreement with a single coordinand is possible in certain syntactic contexts. As in conjunction, disjunctive noun phrases are each marked with a clitic indicating the nature of the coordination. The form of the disjunctive clitic $=r i /=i$ is determined by the phonological properties of the host. The preferred syntax for the expression of disjunctive arguments involves a structure in which the verb follows the first disjunct noun, while second disjunct noun occurs in a postverbal position, as in (10). In structures of this kind, agreement occurs between the first pre-verbal disjunct and the predicate head. For instance, the verb uwqi 'do' in (10a) agrees only with the gender I singular disjunct, Rasuli. The same structure with gender II singular agreement is ungrammatical, as demonstrated by (10b). Semantic agreement with a plural subject is also ungrammatical, as shown in (10c). In these examples, there is strict disjunction between the choice of children, such that only one (either Rasul or Pati) will be brought to the addressee.

$$
\begin{aligned}
& \text { a. wa-ra-k Rasul=i } \quad \text { ir } \quad \text { u<w>-qi Pat'i=ri } \\
& \text { 2SG-CONT-LAT Rasul(I)[SG.ABS]=or behind 〈I.SG〉do-POT Pati(II)[SG.ABS]=or } \\
& \text { 'Should (I) bring you Rasul or Pati?' }
\end{aligned}
$$

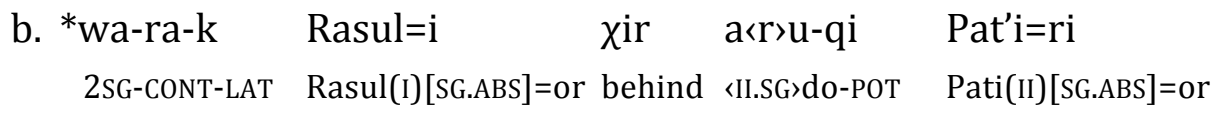

Intended: 'Should (I) bring you Rasul or Pati?'

$$
\begin{aligned}
& \text { c. *wa-ra-k Rasul=i } \quad \text { ir } \quad \text { a } b \text { bsu-qi Pat'i=ri } \\
& \text { 2SG-Cont-LAT Rasul(I)[SG.ABS]=or behind «I/II.PL>do-PoT Pati(II)[SG.ABS]=or }
\end{aligned}
$$

Intended: 'Should (I) bring you Rasul or Pati?'

In verb-initial clauses the preferred agreement is also with the closest disjunct, as in (11a), where the verb agrees only with the gender I singular disjunct, Rasuli. Once again, the same structure with gender II singular agreement is ungrammatical, as demonstrated by (11b). Semantic (plural) agreement is permitted when the disjunctive phrases occur in a post-verbal position, as in (11c).

a. wa-ra-k $\chi$ ir $u\langle w\rangle-q i \quad$ Rasul=i Pat'i=ri 2SG-CONT-LAT behind «I.SG $>$ do-POT Rasul(I)[SG.ABS]=or Pati(II)[SG.ABS]=or 'Should (I) bring you Rasul or Pati?' 
$\begin{array}{llll}\text { b. *wa-ra-k } & \chi \text { ir } \quad \text { a } \ll \text { r }>\text { u-qi } & \text { Rasul=i } & \text { Pat'i=ri } \\ \text { 2sG-CONT-LAT } & \text { behind } \ll \text { «I.SG }>\text { do-POT } & \text { Rasul(I)[SG.ABS]=or Pati(II)[SG.ABS]=or }\end{array}$

Intended: 'Should (I) bring you Rasul or Pati?'

c. wa-ra-k $\chi$ ir a«b>u-qi Rasul=i Pat'i=ri

2SG-CONT-LAT behind «I/II.PL〉do-POT Rasul(I)[SG.ABS]=or Pati(II)[SG.ABS]=or

'Should (I) bring you Rasul or Pati?'

In verb-final clauses, plural agreement is the only possible choice, such that agreement with the first or second (and closest) disjunct, as in (12a) and (12b) respectively, is ungrammatical.

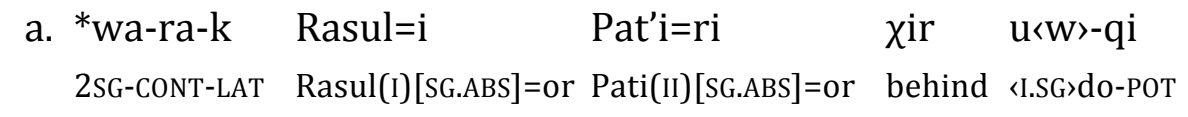
Intended: 'Should (I) bring you Rasul or Pati?'

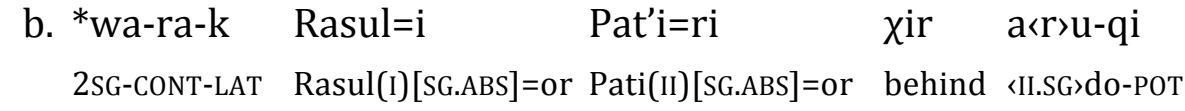
Intended: 'Should (I) bring you Rasul or Pati?'

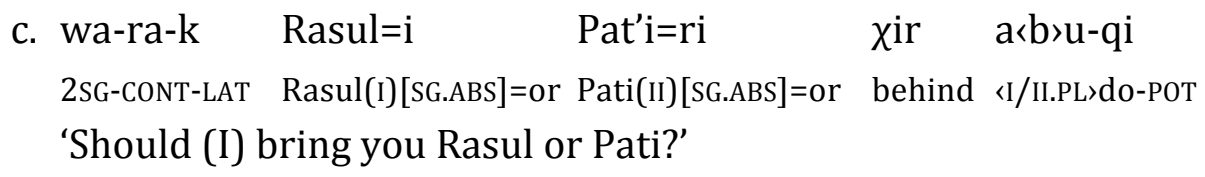

The same constraints on agreement are at work with inanimate disjuncts, as illustrated in (13) where each disjunct has a different gender value. In (13a) the verb appears between the two disjuncts and agrees in gender and number with the pre-verbal head noun phrase, even though the post-verbal disjunct is a different gender. In (13b) the verb occurs in clause final position and exhibits plural agreement, indicating that it does not have to agree with the closest disjunct.

\begin{tabular}{|c|c|c|c|}
\hline was & baquq=i & ba- $\chi$ :a-qi & $o^{\mathrm{S}} \mathrm{rči} \mathrm{i}=\mathrm{ri}$ ? \\
\hline 2SG.DAT & halva(III)[SG.ABS] $=$ or & III.SG-bring-POT & idge(IV)[SG.ABS]=or \\
\hline \multicolumn{4}{|c|}{ 'Should (I) bring you halva or porridge?' } \\
\hline was & go ${ }^{\complement}{ }^{\complement}{ }^{\complement} r c ̌ i=r i$ & baquq $=\mathrm{i}$ & x:a-qi? \\
\hline $\begin{array}{l}\text { 2SG.DAT } \\
\text { 'Should }\end{array}$ & porridge(IV)[SG.ABS]=or & $\begin{array}{l}\text { r halva(III) [SG.ABS] }=\text { or } \\
\text { ge or halva?' }\end{array}$ & [III/IV.PL]bring-POT \\
\hline
\end{tabular}

These data demonstrate that the pattern of agreement with disjunctive co-heads in Archi is determined partially by syntactic factors, such as constituent order.

In concessive disjunction, each co-head that comprises an agreement controlling noun phrase, is marked with the disjunctive clitic =šaw. It is similar in meaning to English or in that it does not have a strictly disjunctive meaning. As with strictly disjunctive arguments, the preferred word order in such constructions is that in which the verb follows the first head in the disjunctive noun phrase, while 
the second noun phrase occurs in post-verbal position. In such cases, agreement is with the preverbal disjunct, as in (14).
(14)
a. baquq=šaw be-še go ${ }^{\text {r }}{ }^{\complement}{ }^{\complement}$ rči $=$ šaw
halva(III)[SG.ABS]=CONC III.SG-bring.IMP[SG] porridge(IV)[SG.ABS]=CONC
'Bring halva or porridge.'

Unlike with conjunction and strict disjunction, singular agreement with the closest co-head to the verb is possible with disjunctive heads marked with $=\check{s} a w$. This is the case for both animate and inanimate nouns, in all word-order configurations, including in verb-final clauses, as in (15a), where the disjunctive noun phrases are both animate, and (15b) with inanimate co-heads. ${ }^{1}$
a. Rasul=šaw
Pat'i=šaw

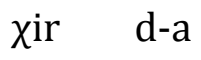
Rasul(I)[SG.ABS] $=$ CONC Pati(II)[SG.ABS] $=$ CONC
behind II.SG-do.IMP[SG]
'Bring Rasul or Pati.'
b. pečena-t:u=šaw $\quad \chi^{\mathrm{w}}$ alli=šaw be-še
biscuit(IV)-PL.ABS=CONC bread(III)[SG.ABS]=CONC III.SG-bring.IMP[SG]
'Bring biscuits or bread.'

Semantic agreement is also permitted with plural noun phrases consisting of humans and other animates. Note that the distinction here is not determined by gender feature values (i.e. syntactic agreement), but according to animacy (i.e. semantic agreement). While noun phrases with co-heads that are human (in genders I and II) or animate (in genders III and IV) can trigger semantic agreement, as in (16a) and (16b) respectively, inanimate nouns of genders III and IV do not, as illustrated by the ungrammatical construction in (16c).
a. Rasul=šaw Pat'i=šaw $\quad$ ir $\quad b-a$
$\operatorname{Rasul(I)[SG.ABS}]=$ CONC Pati(II)[SG.ABS] $=$ CONC behind I/II.PL-do.IMP[SG]
'Bring Rasul or Pati.'
b. motol=šaw $\quad$ dogi=šaw $\chi$ ir a
$\operatorname{kid}(\mathrm{IV})[\mathrm{SG} . \mathrm{ABS}]=\mathrm{CONC} \quad$ donkey(III)[SG.ABS]=CONC behind [III/IV.PL]do.IMP[SG]
'Bring a goat kid or a donkey.'
c. *pečena-t:u=šaw $\quad \chi^{\mathrm{w}}$ alli=šaw še
biscuit(IV)-PL.ABS=CONC bread(III)[SG.ABS]=CONC [III/IV.PL]bring.IMP[SG]
Intended: 'Bring biscuits or bread.'

These facts indicate that syntactic models must be able to incorporate semantic information when accounting for gender and number agreement.

\footnotetext{
1 Structures in which co-heads are of different animacies such as 'Bring either Pati or biscuits' are so semantically incongruous that they have proven difficult to reliably elicit in Archi.
} 


\subsubsection{Numeral phrases}

Like coordinated noun phrases, numeral phrases in Archi - namely those noun phrases in which the lexical head of the phrase is modified by a numeral - are atypical controllers; they exhibit potential for variation in the type of agreement relation they control within the clausal domain. When grammatical features of numeral phrases control syntactic agreement, verbal targets appear in their singular forms, while semantic agreement permits targets to occur in their plural forms. For instance, in (17) each of the verbal targets is controlled by the same absolutive argument consisting of a head noun modified by a numeral and a nominal adjective. In the most commonly encountered pattern, exemplified in (17a), the verb exhibits singular agreement with a controller containing a numeral. In a less common pattern, shown in (17b), the verb exhibits plural agreement.
a. os $\mathrm{i}<\mathrm{w}\rangle \mathrm{di}-\mathrm{li}$
i<w>di-t'u
tiba-w kulu lo
one «I.SG〉be.PST-EVID 〈I.SG〉be.PST-NEG
three-I.SG orphan child(I)[SG.ABS]

'Once upon a time there were three orphan boys.' (T2: 1, = (22), §3.2.4)
b. os e«b`di-li e«b`di-t'u tiba-w kulu lo
one «I/II.PL〉be.PST-EVID «I/II.PL〉be.PST-NEG three-I.SG orphan child(I)[SG.ABS]

'Once upon a time there were three orphan boys.' (based on T2: 1, $=(23), \S 3.2 .4)$

Modifiers that are potential targets for agreement within the nominal domain are controlled by the lexical head of the noun phrase. Therefore, numerals (e.g. dibaw 'three') agree in number and gender with the head they modify, while nominal-adjectives (e.g. kulu 'orphan'), which belong to a non-agreeing lexical class, do not. At the same time, a government-like requirement imposed by the numeral requires that the noun being modified is singular, both in morphological form and in terms of the features relevant for controlling agreement on its agreeing dependents and the verb. Therefore, in (17), the noun phrase dibaw kulu lo 'three orphan boys' has a morphologically singular head noun (imposed by the presence of the numeral) and the numeral agrees with this number feature (rather than a plural one). This property of nouns modified by a numeral gives rise to the two patterns of verbal agreement. The agreement relation in (17a) is a strictly syntactic one in which the verb forms agree with the relevant grammatical properties of the controller, namely gender I singular. In (17b) there is semantic agreement between the verb and the semantic properties of the controller, namely that the nominal referent is semantically plural and human.

The government-like relation imposed by the numeral can be clearly exemplified by the contrast in agreement possibilities between semantically plural subjects that do not have a numeral and those that do. For instance, in imperatives with a subject referring to multiple addressees, the verb may exhibit either syntactic or semantic agreement if a numeral higher than one modifies the subject head, as illustrated by the alternatives in (18). Note that the numeral does not impose the presence of a singular pronoun, but does determine which features are relevant for the syntactic agreement relation in (18a). 
(18) a. $\check{z}^{w}$ en $q^{\prime s}$ werrıu do-ci

2PL.ABS two<II.SG> II.SG-Stand.IMP[SG]

'You two (girls), wait!'

b. $\check{z}^{\mathrm{w}}$ en $\quad \mathrm{q}^{\text {, }}$ we $\mathrm{r}>\mathrm{u}$ oci-r

2PL.ABS two<II.SG $\quad$ [2PL]stand-IMP.PL

'You two (girls), wait!'

The same variation is attested when the numeral is the only overt element in the subject noun phrase, as shown in (19).

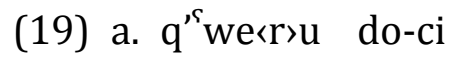

two<II.SG II.SG-stand.IMP[SG]

'You two (girls), wait!'

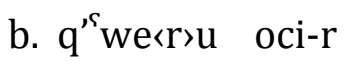

two<II.SG $\quad[2 \mathrm{PL}]$ stand-IMP.PL

'You two (girls), wait!'

When a plural pronoun controller occurs without numeral modification, the verb occurring in the singular is ungrammatical, as in (20).

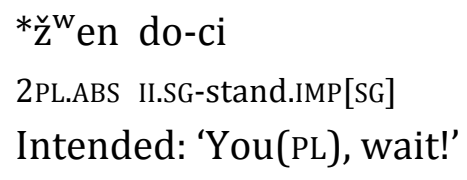

Semantic agreement between numeral phrase controllers and verbal targets is conditioned by animacy, such that only numeral phrases with human referents can trigger semantic agreement. This is illustrated by comparison between the two grammatical possibilities in (17), in which each subject has human referent(s) and the two structures in (21), which have non-human animate subject referents. Syntactic agreement between the singular head of the subject noun phrase is permitted, as in (21a), but semantic agreement with the same phrase is ungrammatical, as illustrated in (21b). The same pattern is seen with inanimate subjects, as demonstrated by the contrast in (22).

\begin{tabular}{|c|c|c|c|}
\hline os & $e<b>d i-l i$ & $e<b>d i-t^{\prime} u$ & arša \\
\hline one & 〈III.SG〉be.PST-EVID & 〈III.SG \be.PST-NEG & Archi.LOC \\
\hline tippu & do:zu-b & ans & \\
\hline thr & G be.big.AT & III.SG bull(III)[SG.ABS & \\
\hline
\end{tabular}

'Once upon a time there were three big bulls in Archi.' 


\begin{tabular}{|c|c|c|}
\hline${ }^{*}$ os edi-li & edi-t'u & arša \\
\hline one [III/IV.PL]be.PST-EVID & [III/IV.PL]be.PST-NEG & Archi.LOC \\
\hline do:zu-b & ans & \\
\hline three.III.SG be.big.ATTR-III.SG & bull(III)[SG.ABS] & \\
\hline
\end{tabular}

Intended: 'Once upon a time there were three big bulls in Archi.'
(22) a. os e«b`di-li e«b»di-t’u tippu qala
one〈III.SG〉be.PST-EVID «III.SG〉be.PST-NEG three.III.SG fortress(III)[SG.ABS]
'Once upon a time there were three fortresses.'
b. *os edi-li edi-t'u tippu qala
one [III/IV.PL]be.PST-EVID [III/IV.PL]be.PST-NEG three.III.SG fortress(III)[SG.ABS]
Intended: 'Once upon a time there were three fortresses.'

Patterns of agreement with the controller in phrases headed by a numeralmodified noun or pronoun may differ across different agreement domains, even within the same syntactic structure. For instance, the construction in (23) demonstrates that it is possible for verbs within a matrix and dependent clause to agree with different values of the same shared agreement controller. The matrix verb bijiwt:uli 'begin' agrees syntactically with the singular number value of the subject jamu dibaw qačas 'these three bandits', while the more distant dependent finalis verb form beq ${ }^{\varsigma}$ es 'go' agrees with semantic features of the subject noun phrase, namely that the subject refers to multiple human referents. ${ }^{2}$

$$
\begin{aligned}
& \text { jamu tiba-w qас̌ав biji<w»ł:u-li be-q`e-s } \\
& \text { that[I.SG] three-I.SG bandit(I)[SG.ABS] «I.SG»begin.PFV-EVID I/II.PL-go-FIN } \\
& \text { gurži-t:-e-qaa-ši } \quad \chi 0 s \quad \chi \text { amlis a-s } \\
& \text { Georgian-PL-PL.OBL-INTER-ALL belongings(IV)[SG.ABS] steal [IV.SG]do-FIN }
\end{aligned}
$$

The variation in (24) shows a similar degree of independence in terms of syntactic/semantic agreement across different domains within a complex sentence. This structure consists of two converbial clauses and a finite matrix clause. The main clause subject nen $q^{\prime s} w e r u$ 'we two' consists of a first-person plural exclusive pronoun quantified by a numeral. It occurs in a clause initial position, and precedes the matrix verb and the two converbial clauses. Recall that when occurring with a plural pronoun, the numeral does not impose that the head is morphologically singular (as it would with a regular noun). It nevertheless exhibits a singular agreement pattern (by way of a gender II singular infix $\langle r\rangle$ ), as found with all numeral modifiers.

\footnotetext{
2 Note that the periphrastic verb form $\chi^{\varsigma}$ amlis as 'do' agrees with its absolutive object $\chi o s$ 'belongings' and therefore its agreement pattern is irrelevant here.
} 


$$
\begin{aligned}
& \text { nen } \quad q^{\prime \varsigma} w e<r>u \quad e^{\varsigma} w w u-r-s ̌ i \quad q^{\prime s} w e<r>u \quad \text { do-q'c'o-li } \\
& \text { 1PL.EXCL[ABS] two〈II.SG cry-IPFV-CVB two<II.SG II.SG-reconcile.PFV-CVB } \\
& \text { q'íjdi-li... } \\
& \text { [1PL]sit.PFV-EVID } \\
& \text { '...we two (girls) were crying, we two (girls) having reconciled (by then) } \\
& \text { were sitting there...' (Based on Sisters: 25) }
\end{aligned}
$$

There are various points of interest concerning agreement controllers and

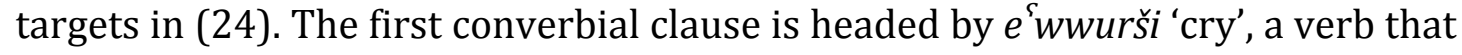
does not have agreement potential, and therefore does not and cannot exhibit any agreement features of its subject (see $\$ 4.4$ for a general discussion of nonagreeing targets; see $\S 5.3$ and $\S 5.4$ for their treatment in HPSG and $\S 6.3 .1$ for an LFG analysis). The second converbial clause is headed by doq'c'oli 'reconcile', while the matrix verb is $q^{\prime} i$ 'jdili 'sit'.

Both of these verbs have the potential to agree, yet while their agreement controllers have identical semantic referents, they agree in different ways. The dependent verb form doq'c'oli 'reconcile' agrees syntactically with the singular features imposed by the presence of the numeral modifier as part of its subject phrase. The lack of agreement affixes on the matrix verb q'i 'ijdili 'sit' indicates that the verb is controlled by a first-person plural subject. Evidence in support of this conclusion, discussed at length in Chumakina, Kibort \& Corbett (2007) comes from the unexpected behaviour of verb-forms controlled by first and second person plural pronouns. ${ }^{3}$

In the singular, Archi personal pronouns trigger gender and number agreement on verbal targets that have agreement potential. However, most of the time there is nothing in the behaviour of verbs that would suggest the need for a person feature. In the singular, male humans trigger gender I agreement and female humans trigger gender II agreement. The marking in the verb is sensitive to the gender of the pronoun's referent, as in (25).

$$
\begin{aligned}
& \text { (25) a. zon w-asıa-r-ši w-i } \\
& \text { 1SG.ABS I.SG-tremble-IPFV-CVB I.SG-be.PRS } \\
& \text { 'I am trembling.' (male speaking) } \\
& \text { b. zon d-as:a-r-ši d-i } \\
& \text { 1SG.ABS II.SG-tremble-IPFV-CVB II.SG-be.PRS } \\
& \text { 'I am trembling.' (female speaking) }
\end{aligned}
$$

While singular pronouns behave like nouns with male/female referents in terms of the agreement relation they control, first and second person plural pronouns referring to humans do not trigger the expected agreement affixes for gender I/II plurals, as indicated by the ungrammatical structure in (26a). Rather, the verbs

3 These data also prove interesting in relation to crossing agreement relations. See $\$ 8.2 .1$ and $\S 8.2 .2$ for discussion. 
with the potential to agree remain unmarked, thus resembling the syntactic agreement pattern associated with non-human plurals, as in (26b).
a. *nen b-as:a-r-ši b-i
1PL.EXCL[ABS] I/II.PL-tremble-IPFV-CVB I/II.PL-be.PRS
Intended: 'We are trembling.'
b. nen
as:a-r-ši
i
1PL.EXCL[ABS] [1PL]tremble-IPFV-CVB [1PL]be.PRS
'We are trembling.'

Chumakina, Kibort \& Corbett (2007) argue that constructions of this kind are evidence for the need for a person feature in Archi. Accepting that the form of the matrix verb in (24) results from semantic, rather than syntactic agreement, (27) provides evidence that both matrix and dependent verbs may agree with semantic features of their controller.

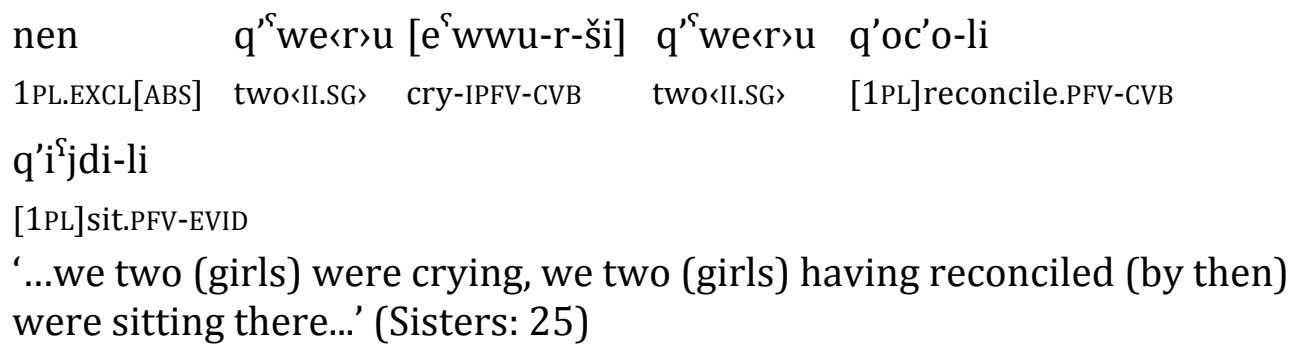

These data from numeral phrases pose a number of problems that must be solved by an adequate syntactic theory. In particular, they raise the question as to what kind of syntactic constraint determines that nouns modified by a numeral must be singular in form. What sort of formal mechanism is needed to account for the double nature of controllers that can determine the presence of semantic agreement in the clausal domain and syntactic agreement in the nominal domain?

\subsection{Competing controllers: Biabsolutive constructions}

Biabsolutive constructions are a transitive clause type found in many languages with ergative-absolutive alignment, especially those of the Nakh-Daghestanian family. The morphosyntax of biabsolutive constructions is characterized by a deviation from the expected alignment pattern for case and agreement, whereby both the subject and object arguments of a verb occur in the absolutive case. Since absolutive arguments in Archi are controllers of agreement within the clausal domain, transitive clauses with two absolutive arguments introduce the potential for competition between two agreement controllers. These interesting 
constructions are carefully discussed in each of the theory chapters (see $§ 5.4 .2$ for HPSG, §6.4 for LFG and §7.3.2.2 for Minimalism). ${ }^{4}$

The imperfective transitive clauses in (28) illustrate the contrast between the ergative-absolutive and biabsolutive alignment strategies. In (28a), the subject of the clause (Butra, man's name) is in the ergative case and the object buq' 'grain' occurs in its (unmarked) absolutive form; in (28b) both the subject and the object of the verb are absolutive. In each case, the imperfective verb form is periphrastic, consisting of an imperfective lexical verb stem and an inflected form of the copula $i$ 'be'.
(28)
a. But:a-mu buq' b-e<r»k'u-r-ši b-i Butta(I)-SG.ERG grain(III)[SG.ABS] III.SG-〈IPFV>Sort-IPFV-CVB III.SG-be.PRS 'Butta is sorting grain.'
b. But:a buq' b-e<r>k'u-r-ši w-i
Butta(I)[SG.ABS] grain(III)[SG.ABS] III.SG-〈IPFV>Sort-IPFV-CVB I.SG-be.PRS
'Butta is sorting grain.' (= (38), §2.4.3.2)

In addition to differences in case-marking, the agreement pattern of the biabsolutive construction also differs from what is normally encountered in Archi. In ergative-absolutive constructions all possible targets agree with the (only) absolutive argument of the clause, as in (28a). The biabsolutive construction provides two possible controllers of agreement and individual components of the periphrastic verb agree with different controllers. Thus, in (28b), the subject absolutive Butra controls the gender I singular agreement on the copula wi 'be' whereas the object absolutive buq' 'grain' controls agreement on the lexical part of the periphrastic form, namely the converb berk'urši 'sort'. Semantic and information-structural differences between the two construction types are examined in $\$ 4.3 .1$.

All known biabsolutive constructions, whether in Daghestanian languages (Kibrik 1975, Harris and Campbell 1995, Forker 2012, Gagliardi, Goncalves, Polinsky \& Radkevich 2014), in Basque (Laka 2006), or in Mayan languages (Coon 2010, 2013) occur only with imperfective verb forms, and Archi biabsolutive constructions are typical in this respect. However, unlike all other languages in the Daghestanian family, where biabsolutives are optional variants of another possible alignment, continuous converbs in Archi obligatorily require biabsolutive alignment. In predicates where the lexical part of the periphrastic verb form is realized by a continuous converb in -mat, only biabsolutive alignment is permitted, as in (29a); ergative-absolutive alignment is ungrammatical, as in (29b).

\footnotetext{
${ }^{4}$ Archi absolutives pose a particular theoretical challenge in that they require separate domains for each of the absolutive arguments, yet evidence indicates that these cannot be treated as canonical Archi main clauses.
} 
$\begin{array}{llll}\text { a. But:a buq' } & \text { b-e«r>k'u-r-mat } & \text { w-i } \\ \text { Butta(I)[SG.ABS] grain(III)[SG.ABS] } & \text { III.SG-<IPFV >sort-IPFV-CVB } & \text { I.SG-be.PRS } \\ \text { 'Butta is (still) sorting grain.' } & \end{array}$

b. *But:a-mu buq' b-e<r>k'u-r-mat b-i

Butta(I)-SG.ERG grain(III)[SG.ABS] III.SG-<IPFV>sort-IPFV-CVB I.SG-be.PRS

Intended: 'Butta is (still) sorting grain.'

Archi is also atypical in that it allows biabsolutive variants not only for predicates that otherwise have ergative-absolutive alignment, but also for those that otherwise have dative subjects; this fact has not been previously reported for Archi. So far, Archi is the only Nakh-Daghestanian language for which the biabsolutive construction based on the dative predicate had been firmly established. Gagliardi et al. (2014) discuss this type of construction for Lak but report only one speaker accepting it.

The alternation between biabsolutive and dative-absolutive alignment is also optional, and restricted to periphrastic imperfective stems. In (30), the periphrastic predicate wakuurši wi 'see' takes the dative-absolutive alignment obligatorily found with the perfective stem of this verb. The experiencer subject lahas 'girl' occurs in in the dative case, and the stimulus dija 'father' occurs in the absolutive. The absolutive object controls gender I singular agreement on both targets of the periphrastic predicate.

$$
\begin{array}{llll}
\text { laha-s } & \text { dija } & \text { w-ak:u-r-ši } & \text { w-i } \\
\text { child(II).SG.OBL-DAT father(I)[SG.ABS] } & \text { I.SG-see-IPFV-CVB } & \text { I.SG-be.PRS } \\
\text { 'A girl sees (her) father.' } & &
\end{array}
$$

In the biabsolutive construction, both arguments take the absolutive case. In (31), the experiencer lo 'girl' controls gender II singular agreement on the copula $d i$, while the stimulus dija 'father' controls the gender I singular agreement on the progressive converb wak'urši 'seeing'.

$$
\begin{array}{llll}
\text { lo } & \text { dija } & \text { w-ak:u-r-ši } & \text { d-i } \\
\text { child(II)[SG.ABS] father(I)[SG.ABS] } & \text { I.SG-see-IPFV-CVB } & \text { II.SG-be.PRS } \\
\text { 'A girl sees (her) father.' } & &
\end{array}
$$

Biabsolutive constructions pose a number of challenges for description and theoretical analysis. Previously, they have been analysed as instances of noun incorporation (Forker 2012) or as instances of clause restructuring (Kibrik 1979, Kazenin \& Testelec 1999, Kazenin 2003). However, the Archi data suggest that neither of these basic analyses is completely viable. In particular, this is demonstrated by the agreement behaviour of non-verbal targets such as adverbs, pronouns and the emphatic clitic in domains containing competing controllers, examined in $§ 4.3 .2$. 


\subsubsection{Semantics of the biabsolutive construction}

There are two types of periphrastic verb form that can license biabsolutive alignment. Both are formed through the combination of a converb (based on the imperfective stem of a lexical verb) and an inflected copula. The continuous converb is realized with the suffix -mat and the progressive converb is realized with the suffix -ši.

The periphrases formed with the continuous converb allow biabsolutive alignment only. The semantics of the continuous converb is roughly that the event predicated about is/was continuing longer than anticipated. As before, the subject controls agreement in gender and number on the copula; the object controls agreement in gender and number on the converb. In (32) the subject Pat'i (a girl's name) determines the gender II singular form of the copula di and the object $q^{\varsigma} w_{i b}$ 'potato' determines the gender III form of borktimmat 'digging'.

$\begin{array}{llll}\text { Pat'i } & q^{{ } w_{i}} \text { ib } & b-0<r>k ł i m-m a t & d-i \\ \text { Pati(II)[SG.ABS] potato(III)[SG.ABS] } & \text { III.SG-<IPFV>dig.IPFV-CVB } & \text { II.SG-be.PRS }\end{array}$

'Pati is still digging the potatoes out.' (She is supposed to have finished a while ago.)

The periphrastic predicate formed using the converb in -ši can head an ergativeabsolutive or a biabsolutive clause. This converb is used to express a broad progressive meaning, and the lexical semantics of the construction is not affected by the type of alignment used.

Biabsolutive constructions rarely occur in narrative texts as main clauses. This is presumably because the discourse function of imperfective clauses in general is to provide contextual information (typically expressed by dependent converbial clauses) rather than the main narrative of a story. However, the distribution of the two alignment systems indicates that the biabsolutive construction can be used in response to questions and to express contrastive focus. The information focus of the biabsolutive may vary, for instance the new information conveyed may be the entire predicate, as in (33) or the object, as in (34). While the subject absolutive is omitted in (33) and (31), the agreement on the predicate shows that it is indeed a biabsolutive construction since the auxiliary agrees with a gender II singular controller and not with the gender III singular object in (30), or the gender IV singular object in (31). The omitted subjects, i.e. Shamsijat and Pat'i (both female names) can be recovered from the question. ${ }^{5}$

\footnotetext{
${ }^{5}$ This example is from spontaneous speech, heard during a dinner with the first author's host family.
} 
In response to: Where is Shamsijat?

$\chi^{\text {Son }} \quad b$-a〈r>ca-r-ši $\quad d-i$

cow(III)[SG.ABS] III.SG-LIPFV>milk-IPFV-CVB II.SG-be.PRS

'(Shamsijat) is milking the cow.'

In response to: What is Pati reading?

q'onq' o<r>ktin-ši d-i

book(IV)[SG.ABS] [IV.SG] $I$ IPFV rread-CVB $\quad$ II.SG-be.PRS

'(Pati) is reading a book.'

Biabsolutive constructions can also be used as an answer to a question where the information focus is the subject, as in (32).

(35) In response to: Who is reading the book?

$\begin{array}{llll}\text { Pat'i } & \text { q'onq' } & \text { orr>ktin-ši } & \text { d-i } \\ \text { Pati(II)[SG.ABS] } & \text { book(IV)[SG.ABS] } & \text { [IV.SG]_IPFv } r \text { read-CVB } & \text { II.SG-be.PRS } \\ \text { 'Pati is reading the book.' } & & \end{array}$

Furthermore, biabsolutive constructions are used for contrasting whole propositions. In (36) the activity of the subject buwa 'mother' is contrasted with the activity of the speaker. While the object is omitted, the word order in (36) is neutral and argument omission is very common and not connected to any specific interpretation. The fact that the object refers to a male referent can be recovered from the gender I singular agreement on the converb $c^{w}$ aršsi 'praising'.

$\begin{array}{llll}\text { buwa } & \text { iqna } & \mathrm{c}^{\mathrm{w}} \mathrm{a}-\mathrm{r}-\mathrm{s} \mathrm{i} & \mathrm{d}-\mathrm{i} \\ \text { mother(II)[SG.ABS] } & \text { always } & \text { I.SG.praise-IPFV-CVB } & \text { II.SG-be.PRS }\end{array}$

'(Well,) MOTHER is always praising him.' (But I cannot say anything about him myself.)

In (37), the biabsolutive construction is used to express a contrast between entire propositions. The event predicated of the subject of the biabsolutive construction is juxtaposed with a different event predicated of a different referent in the previous sentence. The information structure of the clauses is indicated by the use of the biabsolutive construction and the word order. The position immediately before the copula is associated with pragmatically salient elements. In (33) it is contrastive topic. It is marked with the clitic $=u$, which is otherwise used for the coordination of noun phrases.

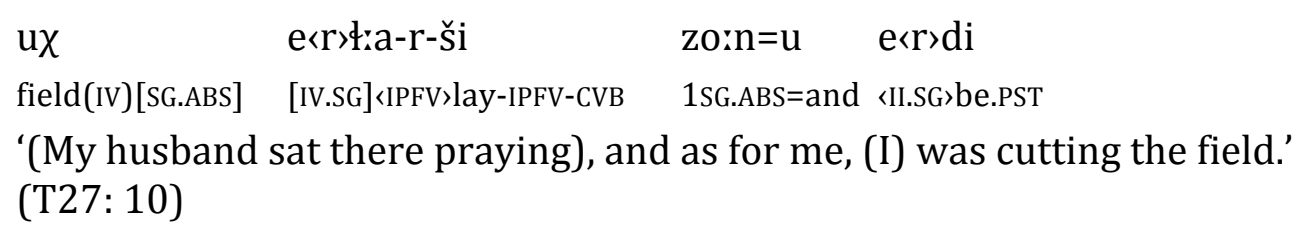


Since biabsolutives are always imperfective, they can be used to describe characteristic behaviour of the subject, as in (38).

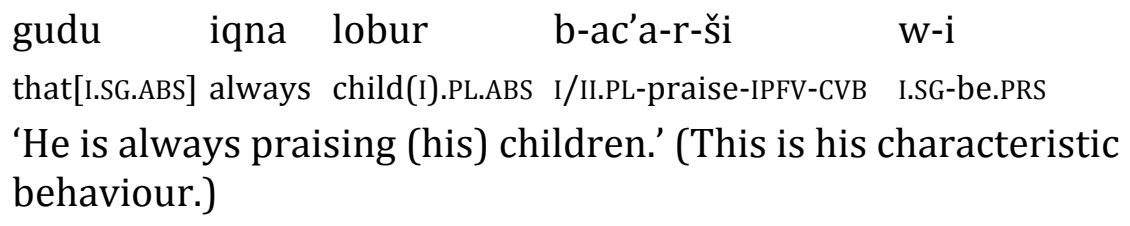

Biabsolutive constructions are commonly used when the object of a verb is generic or typical for the kind of activity denoted by the predicate. Thus, in (39), the verb ocas 'wash' is normally used in the context of washing clothing. This characteristic prompted the interpretation of biabsolutive constructions as a special kind of incorporation by Forker (2012).

$$
\begin{aligned}
& \text { os-l-a malla nasurtin-ni-n jakł'ard } \\
& \text { one-SG.OBL-IN malla nasurtin(I)-SG.OBL-GEN mother.in.law(II)[SG.ABS] } \\
& \text { ha'tər-če-q }{ }^{\varsigma} \quad \text { k'ob } \quad \text { o<r>c:'u-r-ši } \quad \text { e }<r>d i-l i \\
& \text { river(IV)-SG.OBL-INTER clothes(IV)[SG.ABS] [IV.SG]<IPFV〉wash-IPFV-CVB 〈II.SG〉be.PST-EVID }
\end{aligned}
$$

'Once Malla Nasruttin's mother-in-law was washing clothes in a river.' (T8: 1)

There seems to be no semantic requirements on the properties of the subject itself, for example, the subject can be inanimate as well as animate. This observation has not been made before for the Archi biabsolutive, and as far as we are aware, all descriptions and analyses of Nakh-Daghestanian biabsolutives cite examples with animate subjects. When an inanimate noun phrase occurs as the subject of a biabsolutive construction, an instrument typically receives an agent interpretation, as in (40). ${ }^{6}$

(40) a. In response to: Can I borrow your mower?

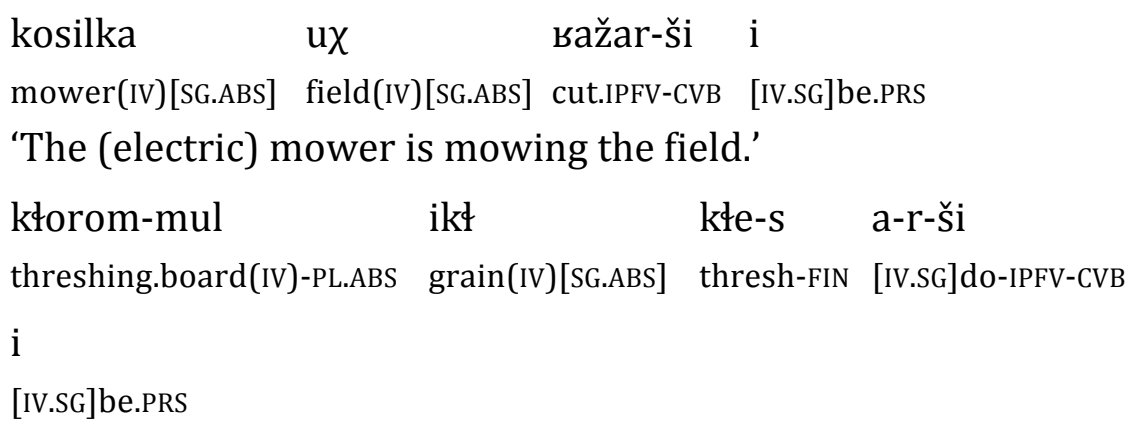

'The threshing boards are threshing the grain.'

c. $\mathrm{k}^{\mathrm{w}}$ am buq' sesor-ši b-i

roasting.sheet(III)[SG.ABS] grain(III)[SG.ABS] roast.IPFV-CVB III.SG-be.PRS

'The roasting sheet is roasting the grain.'

${ }^{6}$ This is also true in transitive constructions with ergative-absolutive alignment. 


\section{d. k'urt'a č'er b-a-r-ši i \\ hammer(IV)[SG.ABS] wall(III)[SG.ABS] III.SG-do-IPFV-CVB [IV.SG]be.PRS}

'The hammer is making the wall.'

Biabsolutive constructions based on the continuous converb in -mat also allow inanimate subjects, as in (41).

$$
\begin{aligned}
& \text { a. kosilka } \quad \text { u } \quad \text { bažar-mat i } \\
& \text { mower(Iv)[SG.ABS] field(IV)[SG.ABS] cut.IPFV-CVB [IV.SG]be.PRS } \\
& \text { 'The (electric) mower is still mowing the field.' }
\end{aligned}
$$
b. kłorom-mul
threshing.board(IV)-PL.ABS grain(IV)[SG.ABS] thresh-FIN [IV.SG]do-IPFV-CVB
i
[IV.SG]be.PRS

'The threshing board is still threshing the grain.'

While these data show that the aspectual semantics of biabsolutive constructions is an important factor in determining possible agreement patterns, we have not found evidence that the semantic characteristics of the absolutive arguments play a role.

\subsubsection{Non-verbal targets in biabsolutive constructions}

There are two possible agreement controllers in biabsolutive constructions, the absolutive subject and the absolutive object (see $\$ 2.4 .3$ for discussion of the term subject in Archi, and $\S 4.3 .3$ on the syntactic status of objects). Just as the agreement properties of periphrastic verbal targets in biabsolutives are determined by one of these competing controllers, so too are the forms of nonverbal agreement targets.

Existing analyses of the syntax of biabsolutive constructions suggest they are monoclausal structures. Kibrik (1979) reflects on the possibility of a biclausal analysis, but argues, on the basis of morphosyntactic evidence, that both biabsolutive arguments are synchronically within the same clause. Forker (2012) also proposes a monoclausal analysis of Archi biabsolutive constructions, suggesting they represent an example of pseudo-incorporation (see $\$ 4.3 .3$ for discussion). To choose between a monoclausal or biclausal analysis, we should look particularly at the agreement behaviour of non-verbal targets and their position within the clause. If a biclausal analysis were correct, one would expect targets to exhibit predictable agreement behaviour constrained by the clausal domain in which the controller and non-verbal target are found. Under a monoclausal analysis, more variable behaviour might be permitted.

In his analysis of Archi biabsolutive constructions, Kibrik (1979: 70) observes restrictions on which argument can control agreement for certain targets, stating that dative obliques and adverbs agree with the subject absolutive only. However, our data show that agreeing items in these lexical classes exhibit more 
variable behaviour in this regard. ${ }^{7}$ To justify this position, we describe in turn how the behaviour of agreeing adverbs (§4.3.2.1), agreeing pronouns ( $\$ 4.3 .2 .2$ ) and the emphatic clitic (§4.3.2.3) differ from those found in constructions with ergative-absolutive alignment.

\subsubsection{Agreeing adverbs in biabsolutive constructions}

In clauses with ergative-absolutive alignment, adverbs with agreement potential are always controlled by the only absolutive argument of their clause (§3.3.4). In the biabsolutive construction, adverbs display more variable agreement, depending on their position in the clause and the semantics of the adverb. (A list of adverbs known to have agreement potential is provided in §4.3.2.) In a biabsolutive construction headed by a periphrastic verb based on a progressive converb, an adverb can agree with either absolutive controller, but only if the semantics of the adverb allow it to be interpreted as modifying either (i) the specific event predicated about (regardless of the subject referent), or (ii) the proposition as a whole. In (42a) the agreeing adverb dit:at'u 'early' can only be interpreted as modifying the predicate since it agrees with the object absolutive $q^{\varsigma} w_{i b}$ 'potato' and therefore occurs in the gender III singular form dit:abu. The same adverb, in the same surface position, can also be interpreted as modifying the whole proposition. For instance, in (42b) the event is construed as happening early in the day (and too early for the subject to be engaged in the activity proposed). In this case, the gender II singular form ditraru agrees with the subject controller.
a. Pat'i
dit:a<b $>\quad q^{{ }^{s}} \mathrm{w} i b$
b-o<r>kdin-ši
d-i
Pati(II)[SG.ABS] early〈III.SG> potato(III)[SG.ABS] III.SG-〈IPFV〉dig.IPFV-CVB II.SG-be.PRS
'Pati is digging the potatoes out early.' (It is too early for the potatoes to be ready.)

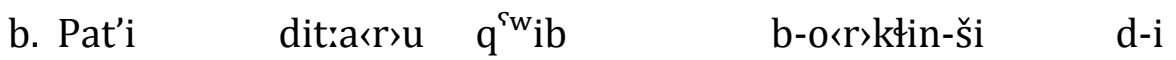
Pati(II)[SG.ABS] early<II.SG> potato(III)[SG.ABS] III.SG-〈IPFV>dig.IPFV-CVB II.SG-be.PRS
'Pati is digging the potatoes out early.' (Pati got up early.)

A similar contrast is illustrated by (43a) and (43b). In (43a), the adverb wallejwu 'for free' agrees in gender (I) and number (SG) with the subject absolutive. Here, the adverb indicates that the subject referent's labour was given away for free. In (43b), it agrees with the gender IV singular object and indicates that the house is being built without cost.

\footnotetext{
${ }^{7}$ It is unclear whether this difference in analysis is the result of language change or whether Kibrik's (1979) observations are based on limited data, since he only cites one example in which there is an agreeing dative and adverb.
} 

a. tu-w
nokł'
a-r-ši
w-i
$\mathrm{w}$-allej〈w〉u
that-I.SG[ABS] house(IV)[SG.ABS] [IV.SG]do-IPFV-CVB I.SG-be.PRS I.SG-for.free〈I.SG>

'He is working for free building the house.'
b. tu-w nokł' a-r-ši
$\mathrm{w}-\mathrm{i}$
allej〈t'>u that-I.SG[ABS] house(IV)[SG.ABS]
[IV.SG]do-IPFV-CVB I.SG-be.PRS [IV.SG] for.free〈IV.SG〉

'He is building the house for free'. (For example, the materials are free.)

However, in some cases, the adverb may agree with the absolutive object only. Thus in (44a) the adverb kellijt'u 'completely' agrees with the object absolutive $q^{\varsigma} w_{i b}$ 'potato' and takes the gender III singular form kellijbu whereas the agreement with the gender II singular absolutive subject is ungrammatical (44b).
Pat'i
completely<III.SG>
Pati(II)[SG.ABS]
a. kellij<b>u
$q^{\varsigma} w_{i b}$

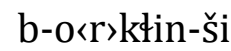
potato(III)[SG.ABS]
III.SG-〈IPFV〉dig.IPFV-CVB
d-i
II.SG-be.PRS

'Pati is digging the potatoes out completely.' (She is digging out all the potatoes.)
b. ${ }^{*}$ kellij $<\mathrm{r}>\mathrm{u}$
Pat'i
$\mathrm{q}^{\mathrm{s}} \mathrm{wib}$
b-o $r$ r kkin-ši
completely〈II.SG〉
Pati(II)[SG.ABS]
potato(III)[SG.ABS]
III.SG-〈IPFV〉dig.IPFV-CVB
d-i
II.SG-be.PRS

Intended: 'Pati is digging the potatoes out completely.'

One might assume that it is the semantics of this particular adverb that precludes agreement with the subject in general; but see the discussion below of this adverb used in the construction with the -mat converb.

The facts about adverbial agreement superficially point towards a biclausal interpretation of the structure of biabsolutive constructions, in which the copula takes a clausal complement. In such an analysis, adverbs that agree with the absolutive object belong to the complement clause, while those that agree with the subject belong to the matrix clauses headed by the copula. Note however that the position of the adverb is largely irrelevant for determining agreement. In (43), the adverb dit:at'u 'early' is positioned between the subject and object regardless of its scope. Similarly, while the higher adverb kellijt'u 'completely' is positioned in the left periphery in (44a), the relevance of its syntactic position should be assessed with some caution since both 'high' and 'low' adverbs can also be positioned at the right periphery of the entire structure, as in (45), where the adverb dit:at'u 'early' agrees with the object absolutive q'onq' 'book'. It is positioned after the copula wi which agrees with the subject absolutive. 


\begin{tabular}{|c|c|c|}
\hline q'onq' & o<r»kdin-ši & $w-i$ \\
\hline that-I.SG[ABS] book(IV)[SG.ABS] & [IV.SG] $/ \mathrm{IPFV}>$ read-CVB & I.SG-be.PRS \\
\hline
\end{tabular}

Again, if we consider this sentence to consist of two clauses, where the clause q'onq' orkfinši 'reading a book' is embedded in the clause headed by the inflected copula wi, which is normal for dependent clause, the position of the adverb makes this interpretation problematic. This issue is taken up in further in the theoretical analyses of later chapters. In $§ 5.4 .3$, for instance, it is used to justify an approach in which sisterhood determines agreement and order domains allow elements to be 'liberated'.

Let us now turn to the constructions headed by the predicate which contains the -mat converb where biabsolutive alignment is obligatory. The picture is different here. Where the adverb allows different semantic interpretation, speakers prefer the variant where the subject absolutive is the controller of agreement on the adverb, as in (46a). However, some speakers allow the object absolutive to be the agreement controller, permitting the interpretation in (46b).
a. Pat'i
dit:a<r>u $q^{{ }^{i} w_{i b}}$
b-orr>ktim-mat
d-i Pati(II)[SG.ABS] early_II.SG> potato(III)[SG.ABS] III.SG-LIPFV〉dig.IPFV-CVB II.SG-be.PRS 'Pati is still digging the potatoes out early.' (Pati got up early.)
b. ?/*Pat'i dit:arb $>q^{\varsigma} w_{i b}$ b-o<r kłim-mat d-i Pati(II)[SG.ABS] early_III.SG> potato(III)[SG.ABS] III.SG-_IPFV>dig.IPFV-CVB II.SG-be.PRS ??'Pati is still digging the potatoes out early.'

When the adverb kellijt'u 'completely' occurs with the continuous periphrastic form, there is less variability between acceptability judgements and most speakers allowed both agreement variants. However, in each case the semantics remain the same, regardless of the agreement controller, as indicated in (47).
a. kellij<b>u
Pat'i
$\mathrm{q}^{\mathrm{s} w} \mathrm{ib}$
b-o<r>kłim-mat completely_III.SG>Pati(II)[SG.ABS] potato(III)[SG.ABS]
III.SG-IPFV>dig.IPPV-CVB
d-i
II.SG-be.PRS

'Pati is still digging the potatoes out completely.' (She has a purpose to empty the potato field, and she is still doing this.)
b. kellij<r>u
Pat'i
$\mathrm{q}^{\text {`wib }}$
b-o<r>ktim-mat
completely đII.SG)
Pati(II)[SG.ABS]
potato(III)[SG.ABS]
III.SG-〈IPFV〉dig.IPFV-CVB
d-i
II.SG-be.PRS

'Pati is still digging the potatoes out completely.' (She has a purpose to empty the potato field, and she is still doing this.) 
As (47) demonstrates, adverbs on the left periphery may exhibit either agreement type. The adverb is also allowed on the right periphery of biabsolutive constructions based on the continuous converb in -mat, as in (48), just as we saw with the constructions headed by the -ši converb.

$$
\begin{aligned}
& \text { tu-w q'onq' o<r>kłim-mat w-i ditra<t'>u } \\
& \text { that-ISG[ABS] book(IV)[SG.ABS] [IV.SG]《IPFV>read-CVB I.SG-be.PRS early〈IV.SG> } \\
& \text { 'He is reading a book early.' }
\end{aligned}
$$

In constructions that are definitely biclausal, the adverb can agree with a controller within its own immediate clause. For instance, each sentence in (49) consists of two clauses. The main clause is headed by $o q^{\varsigma} a$ 'leave' and the dependent one is headed by the concessive converb daq $a s$ š 'although I came'. The adverb ditrat'u 'early' agrees with the subject of this dependent clause and takes the gender II singular form dit:aru, as in (49a). Agreement with the subject of the main clause maršrutka 'minibus' is not grammatical, as in (49b).
a. zon
dit:a<r>u
da-q $q^{\varsigma} a=s ̌ a w$
maršrutka
oq ${ }^{\top} \mathrm{a}$
1.SG.ABS early〈II.SG〉
II.SG-Come.PFV=CONC
minibus(IV)[SG.ABS] [IV.SG]leave.PFV
'Although I came early, the minibus had gone.'
b. *zon
dit:a<t'>u da-q'a=šaw
maršrutka
oq ${ }^{\varsigma} \mathrm{a}$
1.SG.ABS early<IV.SG>
II.SG-come.PFV=CONC
minibus(IV)[SG.ABS] [IV.SG]leave.PFV
Intended: 'Although I came early, the minibus had gone.'

It seems that the agreement behaviour and the positioning of the adverbs in biabsolutive constructions point towards the monoclausal interpretation. Our next problem is the behaviour of the agreeing pronouns in biabsolutive constructions.

\subsubsection{Agreeing pronouns in biabsolutive constructions}

In the Archi personal pronoun paradigm, agreeing forms are found for the dative and genitive case forms of first person pronoun (across the number distinction) and in the ergative of the first person plural inclusive (§3.2.3). By their very nature, ergative pronouns do not occur as arguments in biabsolutive constructions so will not be discussed further here. Since in finite clause the genitive case is only used to mark adjuncts headed by a possessor, and not core arguments, there is no alternation between genitive-absolutive alignment and biabsolutive alignment in Archi (see §2.4.1, §2.5.2 and §3.3.3 for discussion genitive case). However, the dative case is used to encode various oblique arguments in the clause, including non-core arguments in biabsolutive constructions, so we focus on agreeing datives in the following discussion.

In both types of biabsolutive construction, agreement of the dative first person pronoun can be controlled by the object absolutive. Example (50a) shows agreement of a dative pronoun with the absolutive object in a -ši construction, example (50b) shows the same type of agreement in a -mat construction: 

a. buwa
b-ez
$\chi^{\mathrm{w}}$ alli
b-a-r-ši
d-i
mother(II)[SG.ABS]
III.SG-1SG.DAT
bread(III)[SG.ABS]
III.SG-do-IPFV-CVB
II.SG-be.PRS

'Mother is making bread for me.'

b. buwa

b-ez $\quad \chi^{\mathrm{w}}$ alli

b-a-r-mat

d-i

mother(II)[SG.ABS]

III.SG-1SG.DAT

bread(III)[SG.ABS]

III.SG-do-IPFV-CVB

II.SG-be.PRS

'Mother is still making bread for me.'

Three out of ten speakers consulted allow agreement of a dative pronoun with the subject absolutive in -ši constructions, as in (51). The others indicate that it is ungrammatical.

$$
\begin{array}{lllll}
\text { ?buwa } & \text { d-ez } & \chi^{\mathrm{w}} \text { alli } & \text { b-a-r-ši } & \text { d-i } \\
\text { mother(II)[SG.ABS] } & \text { II.SG-1SG.DAT } & \text { bread(III)[SG.ABS] } & \text { III.SG-do-IPFV-CVB } & \text { II.SG-be.PRS }
\end{array}
$$

???'Mother is making bread for me.'

Turning to the -mat construction, all speakers concur that the agreement of the dative pronoun with the subject absolutive is ungrammatical, as in (52). (Recall that the gender marker on the pronoun is an agreement marker; it does not indicate the sex of the beneficiary.)

$$
\begin{aligned}
& \begin{array}{llll}
\text { a. *dija } & \text { W-ez } & \text { iqna-t:u-t } & \text { ari } \\
\text { father(I)[SG.ABS] } & \text { I.SG-1SG.DAT } & \text { day(IV).IN-ATTR-IV.SG } & \text { work(IV)[SG.ABS] }
\end{array} \\
& \text { kło-r-mat } \quad \mathrm{w} \text {-i } \\
& \text { [IV.SG]give-IPFV-CVB I.SG-be.PRS } \\
& \text { Intended: 'Father is still giving me a day's work.' } \\
& \text { b. }{ }^{*} \text { tu-w b-is televizor w-ez } \\
& \text { that-I.SG[ABS] III.SG-1SG.GEN TV.set(III)[SG.ABS] I.SG-1SG.DAT } \\
& \text { mu b-a-r-mat w-i } \\
& \text { be.good III.SG-do-IPFV-CVB I.SG-be.PRS }
\end{aligned}
$$

Intended: 'He is still fixing my TV set for me.'

The attested agreement pattern differs from the previous proposal: in his paper on the Archi biabsolutive, Kibrik (1979: 70) states that datives agree with the subject absolutive.

Agreement with the object absolutive seems to be in line with a biclausal interpretation. If the biabsolutive construction means something like 'A is Xing $\mathrm{P}$ for R', we would expect the recipient or beneficiary argument (R) to be in the lower clause, i.e. in the clause predicating the action itself. However, the position of the dative pronoun argues against a biclausal interpretation of biabsolutive constructions since both types of converb allow the positioning of a dative indirect object at the right periphery, as illustrated in (53). 

$\begin{array}{llll}\text { a. tu-w q'onq' } & \text { o } r \text { r }>\text { kłin-ši } & \text { w-i } & \text { ez } \\ \text { that-I.SG[ABS] book(IV)[SG.ABS] } & {[\mathrm{IV} . S G] \ll I P F V>r e a d-C V B} & \text { I.SG-be.PRS } & \text { [IV.SG]1SG.DAT }\end{array}$
'He is reading me a book.'
b. tu-w q'onq' o<r>kłim-mat w-i ez that-I.SG[ABS] book(IV)[SG.ABS] [IV.SG] IIPFV>read-CVB I.SG-be.PRS [IV.SG]1SG.DAT 'He is still reading me a book.'

In both constructions, the pronoun $e z$ 'for me' agrees with the gender IV singular object q'onq' 'book' while being positioned after the copula wi, which itself agrees with the gender I singular subject absolutive tuw 'he'. Example (54) illustrates the same point. We cite this specific example here since the dative pronoun has an overt gender marker $b$ - agreeing in gender III singular with the object absolutive televizor 'TV set'. This demonstrates that the dative indeed agrees with the object absolutive rather than having a default agreement form (i.e. it does not have to bear the gender IV singular form by default).

$\begin{array}{llll}\text { tu-w } & \text { b-is } & \text { televizor } \quad \text { mu } & \text { b-a-r-mat } \\ \text { that-I.SG[ABS] } & \text { III.SG-1SG.GEN } & \text { TV.set(III)[SG.ABS] be.good } & \text { III.SG-do-IPFV-CVB } \\ \text { w-i } & \text { b-ez } & & \\ \text { I.SG-be.PRS } & \text { III.SG-1SG.DAT } & \\ \text { 'He is still fixing my TV set for me.' }\end{array}$

Agreeing dative pronouns therefore show the same picture as the adverbs. The properties of agreement alone would point towards a biclausal interpretation (even more so since only one agreement strategy is accepted by all speakers) but the facts about the word order make the picture more complicated.

\subsubsection{Agreeing emphatic clitic in biabsolutive constructions}

The emphatic clitic =ejt'u can attach to any constituent and agrees with the absolutive argument of the clause (see $\$ 3.3 .6$ for details). In biabsolutive constructions, agreement of the emphatic clitic can be controlled by the object absolutive only. The constructions in (55) illustrate this pattern for periphrastic forms headed by the -ši converb. In (55a), the emphatic clitic agrees in number

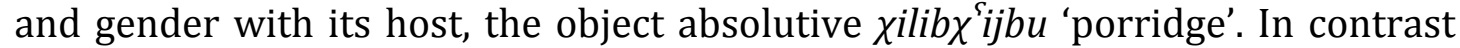
(55b) shows that the agreement with the subject absolutive lo 'girl' is ungrammatical. 
(55) a. lo

$$
\chi \text { ilib } \chi^{\varsigma} \mathrm{i}=\mathrm{j}<\mathrm{b}>\mathrm{u} \quad \text { bu-kan-ši } \quad \text { e<r>di }
$$

child(II)[SG.ABS] porridge(III)[SG.ABS]=EMPH〈III.SG〉III.SG-eat.IPFV-CVB 〈II.SG〉be.PST

akł' kummu-s kilaw

meat(IV)[SG.ABS] [IV.SG] eat.IPFV-FIN than

'The girl was eating the porridge, she likes it better than eating meat.' (lit. 'rather than to eat meat')

b. *lo

child(II)[SG.ABS]

$\chi$ ilib $\chi^{\varsigma} \mathrm{i}-\mathrm{j}\langle\mathrm{r}>\mathrm{u}$

bu-kan-ši e err〉di

akł'

porridge(III)[SG.ABS]=EMPH〈II.SG〉

III.SG-eat.IPFV-CVB 〈II.SG $>$ be.PST

meat(IV)[SG.ABS]

kummu-s kilaw

'The girl was eating the porridge, she likes it better than eating meat.'

Example (56) illustrates the same point for constructions with the -mat converb.
a. lo
$\chi$ ilib $\chi^{\varsigma} \mathrm{i}=\mathrm{j}<\mathrm{b}>\mathrm{u}$
bu-kam-mat
child(II)[SG.ABS] porridge(III)[SG.ABS]=EMPH〈III.SG> III.SG-eat.IPFV-CVB

e $\ll$ r di akł' kummu-s kilaw
〈II.SG >be.PST meat(IV)[SG.ABS] [IV.SG] eat.IPFV-FIN than

'The girl was eating the porridge, she likes it better than eating meat.'

b. *lo $\quad \chi$ ilib $\chi^{\varsigma} \mathrm{i}=\mathrm{j}\langle\mathrm{r}>\mathrm{u} \quad$ bu-kam-mat $\mathrm{e}<\mathrm{r}>\mathrm{di}$

child(II)[SG.ABS] porridge(III)[SG.ABS]=EMPH〈II.SG〉 III.SG-eat.IPFV-CVB 〈II.SG〉be.PST

akd' kummu-s kilaw

meat(IV)[SG.ABS] [IV.SG] eat.IPFV-FIN than

'The girl was eating the porridge, she likes it better than eating meat.'

In general, the agreement behaviour of the emphatic clitic points towards a biclausal structure. This goes against the trend of the other diagnostics we have identified. The emphatic clitic never agrees across a clause boundary in other construction types, as demonstrated by the contrast in (57).

a. lo

$$
\text { jamu-t bank:a=j<t'>u }
$$

ox:a-li

$\mathrm{uq}^{\mathrm{S}} \mathrm{a}$

child(I)[SG.ABS] this-IV.SG jar(IV)[SG.ABS]=EMPH/IV.SG> [IV.SG]take.PFV-CVB I.SG.leave.PFV 'Having taken this jar, the boy left'.
b. *lo
jamu-t bank:a=j〈w〉u
ox:a-li
$\mathrm{uq}^{\mathrm{S}} \mathrm{a}$
child(I)[SG.ABS] this-IV.SG jar(IV)[SG.ABS]=EMPH〈I.SG> [IV.SG]take.PFV-CVB $\quad$ I.SG.leave.PFV
Intended: 'Having taken this jar, the boy left.'

In (57), the head of the main clause is $u q^{\S} a$ 'left', the oblique dependent clause is jamut bankrajt'u ox:ali 'having taken that jar'. The ergative subject of 'take' is coreferential with the argument of the main and is thus omitted. The emphatic clitic belongs to the dependent clause, and thus cannot agree with the absolutive subject of the main clause. 


\subsubsection{The syntactic status of absolutive objects}

In her analysis of Daghestanian biabsolutives, Forker (2012) proposes that the biabsolutive construction is a particular case of noun (object) incorporation, which she terms 'pseudo-incorporation'. She claims that while there is no phonological bleaching and no morphological integration of the object argument with the verb, the erstwhile object nevertheless gets syntactically demoted from a core argument role in biabsolutive constructions.

However, our data demonstrate that object absolutives in biabsolutive constructions behave like distinct syntactic constituents that can be separated from the converb by an intervening adjunct ( $\$ 4.3 .3 .1)$, and can be modified, like other nominals, by demonstratives (§4.3.3.2). As a separate syntactic constituent, the object absolutive has the same syntactic possibilities as the subject absolutive in terms of its availability for dislocation (§4.3.3.3), its ability to be questioned (§4.3.3.4) and its ability to be replaced by a pronoun ( $\$ 4.3 .3 .5)$. The subjects and objects of biabsolutives can be distinguished based on their ability to be relativized $(\S 4.3 .3 .6)$.

\subsubsection{Separation of the object from the converb}

Objects of converbs in biabsolutive constructions can be separated from the verb of which they are a dependent even when they remain in the most common APV constituent order. Intervening material between the object and verb is allowed with both converbs. In (58a) the adverb o:kurši 'slowly' is positioned between the object absolutive and a -ši converb, while in (58b) this adverb is used before a -mat converb.
a. Pat'i
$\mathrm{q}^{\mathrm{w}} \mathrm{ib}$
o:kurši
b-o $r$ r kdin-ši
d-i
Pati(II)[SG.ABS] potato(III)[SG.ABS] slowly
III.SG-〈IPFV〉dig-CVB II.SG-be.PRS
'Pati is digging potatoes slowly.'
b. Pat'i
$\mathrm{q}^{\mathrm{w}} \mathrm{ib}$
o:kurši
b-o<r kkim-mat $d-i$
Pati(II)[SG.ABS] potato(III)[SG.ABS] slowly
III.SG-〈IPFV〉dig-CVB II.SG-be.PRS
'Pati is still digging potatoes slowly.'

This demonstrates that the object of the verb is not syntactically incorporated, but forms part of a phrase built from distinct syntactic constituents.

\subsubsection{Modification}

Like other nominal constituents, absolutive objects in biabsolutive constructions can be modified by a demonstrative. Example (59) demonstrates this possibility for the -si and -mat converbs when the object occurs in the usual pre-verbal position.
a. Pat'i
ja-b gyzijt
b-o $r$ r kdin-ši
d-i
Pati(II)[SG.ABS] this-III.SG newspaper(III)[SG.ABS] III.SG-〈IPFV>read-CVB
II.SG-be.PRS
'Pati is reading this newspaper.' 

b. Pat'i
ja-b
gyzijt
b-o $<$ r kdim-mat $\quad d-i$
Pati(II)[SG.ABS] this-III.SG
newspaper(III)[SG.ABS]
III.SG-LIPFV〉read-CVB II.SG-be.PRS
'Pati is still reading this newspaper.'

\subsubsection{Dislocation}

Like other arguments, the object absolutive in a biabsolutive construction can be focussed or topicalized through dislocation: right dislocation - used for pragmatically salient elements - is always allowed but note that the rightmost position can also be used for afterthoughts (pronounced after a pause in natural speech, but hard to assess in an elicited examples). The sentence in (60a) illustrates this possibility for an object of the -ši converb, while (60b) illustrates that right dislocation is also possible with the object of the -mat converb.
a. Pat'i
b-o $r$ r kdin-ši
$\mathrm{d}-\mathrm{i}$
gyzijt
Pati(II)[SG.ABS] III.SG-<IPFV>read-CVB
II.SG-be.PRS
newspaper(III)[SG.ABS]
'Pati is reading a newspaper.'

b. buwa

b-a-r-mat

$d-i$

$\chi^{\varsigma}$ ošon

mother(II)[SG.ABS]

III.SG-do-IPFV-CVB

II.SG-be.PRS

dress(III)[SG.ABS]

'Mother is still making a dress.'

Left dislocation, which is used for topicalization, is also found with the objects of converbs, as demonstrated in (61) for biabsolutives with -ši and -mat converbs.
a. ja-b
gyzijt
Pat'i=wu
b-o<r>kłin-ši
$d-i$
this-III.SG newspaper(III)[SG.ABS] Pati(II)[SG.ABS]=and III.SG-کIPFV>read-CVB II.SG-be.PRS 'Pati is also reading this newspaper.' (lit. 'This newspaper, Pati is also reading it.)
b. ja-b gyzijt
Pat'i=wu
b-o<r>ktim-mat d-i
this-III.SG newspaper(III)[SG.ABS] Pati(II)[SG.ABS]=and III.SG-LIPFV>read-CVB II.SG-be.PRS 'Pati is also still reading this newspaper.' (lit. 'This newspaper, Pati is still also reading it.)

Left dislocated topicalized elements may also be marked by the discourse marker -či; it can mark topicalization of a subject absolutive, as in (62a), or topicalization of an object absolutive, as in (62b).
a. buwa-či
$\chi^{\mathrm{w}}$ alli
b-ar-ši
d-i
mother(II)[SG.ABS]-TOP
bread(III)[SG.ABS] III.SG-do-IPFV-CVB
II.SG-be.PRS
un han
a-r-ši
$w-i$
2SG.ABS what(IV)[SG.ABS] [IV.SG]do-IPFV-CVB I.SG-be.PRS
'As for mother, she is making the bread, so what are you doing?' 

b. $\chi^{\mathrm{w}}$ alli-či buwa b-a-r-ši $\quad \mathrm{d}-\mathrm{i}$
bread(III)[SG.ABS]-TOP mother(II)[SG.ABS] III.SG-do-IPFV-CVB II.SG-be.PRS
goro'rči
porridge(IV)[SG.ABS] who.ERG [IV.SG]do-POT

'As for the bread, mother is making it, so who will make the porridge?'

Topicalization of the object is also permitted in biabsolutives constructions with the -mat converb, as illustrated in (63).

$\begin{array}{lllll}\text { mišin-či } & \text { But:a } & \text { mu } & \text { a-r-mat } & \text { w-i } \\ \text { car(IV)[SG.ABS]-TOP } & \text { Butta(I)[SG.ABS] } & \text { be.good } & \text { [IV.SG]do-IPFV-CVB } & \text { I.SG-be.PRS } \\ \text { televizor } & \text { fi } \quad \text { mu } & \text { a〈b`u-qi } & \\ \text { TV.set(III)[SG.ABS] } & \text { who.ERG be.good } & \text { 〈III.SG〉do-POT } \\ \text { 'As for the car, Butta is still fixing it, but who will fix the TV set?' }\end{array}$

These data also point to an analysis in which the object of a periphrastic verb form exhibits syntactic autonomy.

\subsubsection{Questioning and focussing}

A further distributional property that demonstrates the syntactic independence of the object of converbs in biabsolutive constructions is the possibility of questioning it. Both types of biabsolutive construction allow their objects to be questioned, as shown in (64).
a. han
Pat'i
o<r〉kdin-ši
$\mathrm{d}-\mathrm{i}$ ?
what(IV)[SG.ABS] Pati(II)[SG.ABS]
[IV.SG]《IPFV>read-CVB II.SG-be.PRS
'What is Pati reading?'
b. han
$\mathrm{mu}$
a-r-mat
$w-i$
gudu?
what(IV)[SG.ABS] be.good
[IV.SG]do-IPFV-CVB I.SG-be.PRS that[I.SG.ABS]
'What is he (still) fixing?'

It is also possible for the object of a biabsolutive construction to be in contrastive focus, as in (65).

(65) In response to: 'They were building the bridge.'

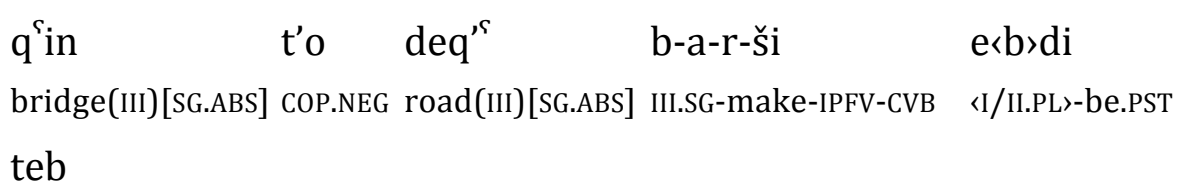

they.PL.ABS

'Not the bridge, they were building a road.'

In any model of grammar that equates the ability to be focused with syntactic constituency, these data serve as evidence for status of converbial objects as independent constituents. 


\subsubsection{Pronominal replacement}

Like other object arguments, the object of a converb in a biabsolutive construction can also be expressed by a pronominal form, as illustrated with the pronoun jab 'it' in (66).

(66)
a. Pat'i
ja-b
b-o<r>kłin-ši
d-i
Pati(II)[SG.ABS] this-III.SG[ABS]
III.SG-<IPFV〉read-CVB
II.SG-be.PRS
'Pati is reading it.'
b. Pat'i
ja-b
b-o<r>kłim-mat
$d-i$
Pati(II)[SG.ABS] this-III.SG[ABS]
III.SG-〈IPFV read-CVB
II.SG-be.PRS
'Pati is still reading it.'

Pronominal replacement of this kind serves as further evidence for the syntactic independence of converbial objects.

\subsubsection{Relativization}

The only property that distinguishes syntactic behaviour of the subject in biabsolutive constructions from that of the object is relativization. Relative clauses are formed through the use of a deverbal attributive (§3.1.2). Normally, any Archi argument can be relativized on in this way, all the way down the accessibility hierarchy (Keenan \& Comrie 1977). In biabsolutive constructions, the only argument which cannot be relativized is the object, as illustrated in (67).

$\begin{array}{lllll}\text { *buwa } & \text { b-a-r-ši } & \text { d-i-t:u-b } & \text { X } \\ \text { mother(II)[SG.ABS] } & \text { III.SG-make-IPFV-CVB } & \text { II.SG-be.PRS-ATTR-III.SG } & \text { dress(III)[SG.ABS] } \\ \text { b-ez } & \text { kł'an } & & & \\ \text { III.SG-1.DAT } & \text { like } & & & \end{array}$

Intended: 'I like the dress mother is making.'

In (67), the agreement on the copula ditub and the case marking on buwa 'mother' (or, rather, the absence of case marking as it is the absolutive) demonstrate that it is indeed a relativized biabsolutive construction. Relativization of the subject of the same biabsolutive construction is allowed, as demonstrated in (68).

$$
\begin{array}{llll}
\chi^{\text {S}} \text { ošon } & \text { b-a-r-ši } & \text { d-i-t:u-r } & \text { buwa } \\
\text { dress(III)[SG.ABS] } & \text { III.SG-make-IPFV-CVB } & \text { II.SG-be.PRS-ATTR-II.SG } & \text { mother(II)[SG.ABS] } \\
\text { 'mother who is making a dress' } & &
\end{array}
$$

The fact that the converb and copula can have different agreement controllers, as in (68), is a clear indicator that the base for relativization is a biabsolutive construction. If the subject of an ergative-absolutive progressive sentence is relativized on, both the converb and copula agree with the absolutive object, as seen in (69). 
When the object of an ergative-absolutive progressive sentence is relativized on, the converb and copula also both agree with the absolutive object, as seen in (70).

$\begin{array}{llll}\text { buwa } & \text { b-a-r-ši } & \text { b-i-t:u-b } & \chi^{\text {Sošon }} \\ \text { mother(II)[SG.ABS] } & \text { III.SG-make-IPFV-CVB } & \text { III.SG-be.PRS-ATTR-III.SG } & \text { dress(III)[SG.ABS] } \\ \text { b-ez kf'an } & & \\ \text { III.SG-1.DAT like } & \\ \text { 'I like the dress } & \text { Mother is making.' }\end{array}$

As with -si converbs, the object of a biabsolutive construction headed by the -mat converb also cannot be relativized either, as shown by the ungrammatical examples in (71).

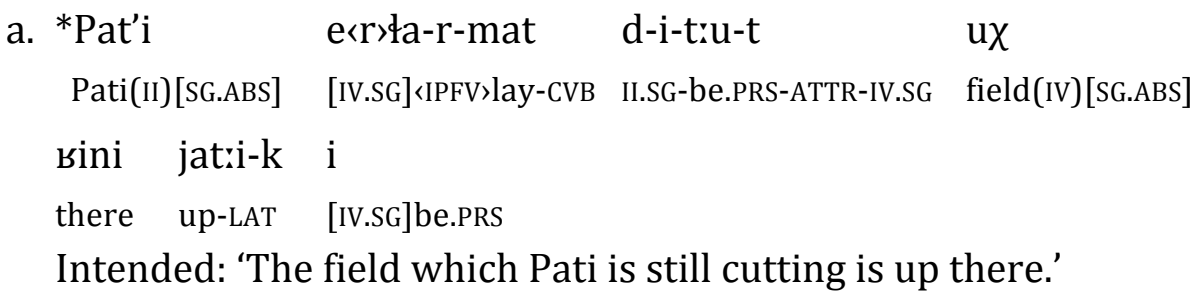

Intended: 'The car which he is still repairing is at our place.'

However, relativization of the subject absolutive of this construction is grammatical, as shown in (72).

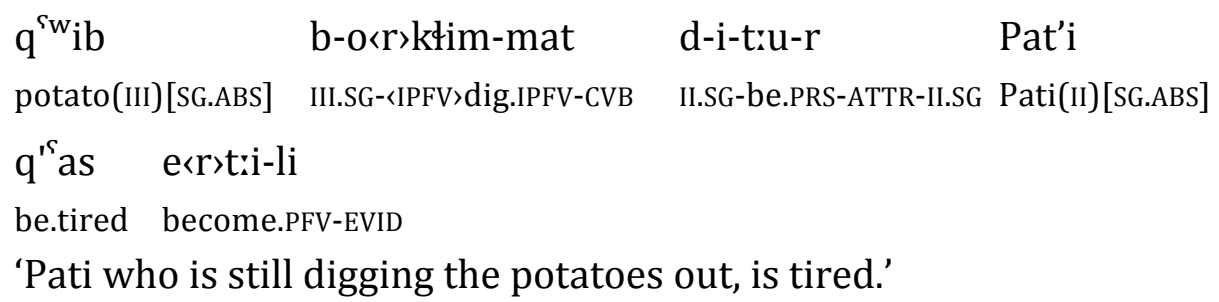

These data demonstrate that an adequate syntactic model of the biabsolutive construction in Archi must be able to account for the gradient syntactic behaviour of converbial objects - specifically, why they differ from other objects in terms of their availability for relativization. More generally, the evidence points to the syntactic autonomy of absolutive objects in biabsolutive 
constructions and represents a challenge to Forker's (2012) 'pseudoincorporation' proposal.

\subsubsection{Biabsolutive construction vs. predicative complements}

When the noun is used in the predicative complement position, it takes the form of the absolutive and therefore clauses with nominal predicates have a formal resemblance to biabsolutive constructions, as illustrated in (73).

$$
\begin{array}{lll}
\text { tu-w tuxt'ur } & \text { w-i } \\
\text { that-I.SG[ABS] } & \text { doctor(I)[SG.ABS] } & \text { I.SG-be.PRS } \\
\text { 'He is a doctor.' } &
\end{array}
$$

Normally, the subject and the predicative complement are of the same gender and there is no way of determining which nominal head controls agreement. However, if they each belong to different genders, the copula can take either agreement. In (74a) the copula agrees with the subject in gender II whereas in (74b) the copula agrees in gender (III) with the predicative complement čan 'sheep'.
(74)
a. to-r čan d-i
that-II.SG[ABS] sheep(III)[SG.ABS] II.SG-be.PRS
'She is stupid.' (lit. 'She is a sheep.')
b. to-r čan b-i
that-II.SG[ABS] sheep(III)[SG.ABS] III.SG-be.PRS
'She is stupid.' (lit. 'She is a sheep.')

However, the predicative complement does not have the same syntactic role as absolutive objects in biabsolutive constructions, or as objects in general. The difference can be seen in the behaviour of anaphoric pronouns. In case of the genuine object, an anaphoric pronoun in the next adjacent clause can refer to it. Compare the following sentences. In (75) the pronoun juw 'he' refers to the subject of the preceding clause ('Ali'), while in (76) the pronoun jab 'it' refers to the object in the preceding clause (č'an 'sheep'). The pronouns are gender I and gender III respectively and the verb cas 'praise' agrees accordingly.

$\begin{array}{lll}\text { Iali-mu } & \text { č'an } & \text { be-šde-li } \\ \text { Ali(I)-SG.ERG } & \text { sheep(III)[SG.ABS] } & \text { III.SG-buy.PFV-CVB } \\ \text { buwa-mu } & \text { ju-w } \quad \text { cu } \\ \text { mother(II)-SG.ERG } & \text { that-I.SG[ABS] I.SG.praise.PFV } \\ \text { 'Ali bought a sheep and mother praised him (i.e. Ali).' }\end{array}$




$\begin{array}{lcl}\text { Sali-mu } & \text { č'an } & \text { be-šde-li } \\ \text { Ali(I)-SG.ERG } & \text { sheep(III)[SG.ABS] } & \text { III.SG-buy.PFV-CVB } \\ \text { buwa-mu } & \text { ja-b } & \text { bo-co } \\ \text { mother(II)-SG.ERG } & \text { that-III.SG[ABS] } & \text { III.SG-praise.PFV }\end{array}$

'Ali bought a sheep and mother praised it (i.e. the sheep).'

The pronoun can also refer to the whole situation described by the first clause, as in (77), and then it will be gender IV.

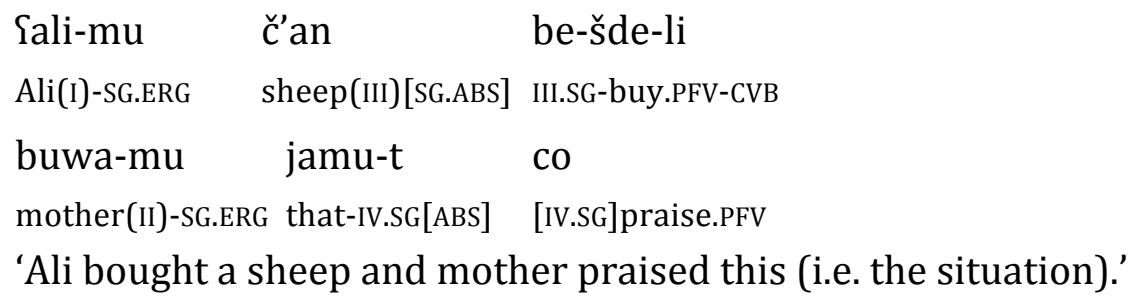

However, if the second absolutive is a predicative complement, it cannot be referred to by a pronoun in the following clause. Compare (78a) where the pronoun refers to the absolutive subject tor 'she' and its ungrammatical counterpart in (78b).

a. to-r č'an b-i

that-II.SG[ABS] sheep(III)[SG.ABS] III.SG-be.PRS

ammo buwa-mu ja-r do-co

but mother(II)-SG.ERG that-II.SG[ABS] II.SG-praise.PFV

'She is a stupid (lit. a sheep) but mother praised her.'

b. *to-r č'an b-i

that-II.SG[ABS] sheep(III)[SG.ABS] III.SG-be.PRS

ammo buwa-mu ja-b bo-co

but mother(II)-SG.ERG that-III.SG[ABS] III.SG-praise.PFV

Intended: 'She is stupid (lit. a sheep) but mother praised it (i.e. the sheep).'

While anaphoric reference to a predicate complement is ungrammatical, reference to the whole situation is possible, as illustrated in (79).

$$
\begin{aligned}
& \text { to-r čan b-i } \\
& \text { that-II.SG[ABS] sheep(III)[SG.ABS] III.SG-be.PRS } \\
& \text { ammo buwa-mu jamu-t co } \\
& \text { but mother(II)-SG.ERG that-IV.SG[ABS] [IV.SG]praise.PFV }
\end{aligned}
$$

'She is stupid (lit. a sheep) but mother praised it (i.e. the situation).' 
Nominal predications formed with the periphrastic verb 'to become' have an even stronger formal resemblance to a biabsolutive construction in the form of the predicate, as in (80).

$$
\begin{array}{llll}
\text { to-r } & \text { čan } & \text { de-ke-r-ši } & \text { d-i } \\
\text { that-II.SG[ABS] } & \text { sheep(III)[SG.ABS] } & \text { II.SG-become-IPFV-CVB } & \text { II.SG-be.PRS } \\
\text { 'She is getting stupid.' (lit. 'She is becoming a sheep.') }
\end{array}
$$

Note, however, that in (80) the agreement is with the gender II singular absolutive subject, and this is the only possible agreement. If this were a genuine biabsolutive construction we would expect the converb to agree with the object absolutive and the copula with the subject absolutive. However, as demonstrated by (81), this agreement is ungrammatical.

$$
\begin{array}{llll}
\text { *to-r } \quad \text { č'an } & \text { be-ke-r-ši } & \text { d-i } \\
\text { that-II.SG[ABS] } & \text { sheep(III)[SG.ABS] } & \text { III.SG-become-IPFV-CVB } & \text { II.SG-be.PRS } \\
\text { Intended: 'She is getting stupid.' (lit. 'She is becoming a sheep.') }
\end{array}
$$

These differences suggest that different syntactic accounts are required for genuine biabsolutive constructions and predicate nominals with an absolutive complement.

\subsection{Agreement potential}

It is sometimes assumed that members of a word class behave identically in terms of their ability to participate in morphosyntactic processes. However, agreement in Archi never pervades every member of a category; with the exception of attributives - which themselves are always transposed from some other lexical class, there is no single word class where every member has the potential to agree. Around a third of verbs, a handful of adverbs, a single postposition and the emphatic enclitic have agreement potential in Archi, as demonstrated by the data in Table 1 . This presents a challenge for theoretical approaches to parts of speech that anticipate uniformity as a normal characteristic of lexical classes. This issue is addressed by Borsley for HPSG in $\S 5.3$ and $\$ 5.4 .1$. Sadler's LFG analysis also treats non-agreement as a morphological matter, as indicated at the end of §6.3.1. In Polinsky's Minimalist analysis, some of the sporadic agreement is seen as a reflection of underlying syntax. For instance, the non-agreeing verb 'know' is argued to be 'be known to someone' involving a PP structure that blocks probing and requires a null exponent (gender IV) in all contexts (see §7.4.2). It is not clear, however, that all non-agreeing verbs could be accounted for in this way, as discussed in $§ 4.4 .1$. 
Table 4.1. Lexical items with agreement potential, based on data from the Archi dictionary, reported in Chumakina \& Corbett (2015)

\begin{tabular}{|l|r|r|r|}
\hline & TOTAL & AGREEING & \% AGREEING \\
\hline VERBS & 1248 & 399 & 32.0 \\
\hline ADVERBS & 383 & 13 & 3.6 \\
\hline POSTPOSITIONS & 34 & 1 & 2.9 \\
\hline DISCOURSE CLITICS/PARTICLES & 4 & 1 & 25.0 \\
\hline
\end{tabular}

For discussion of agreeing and non-agreeing pronouns, see §3.3.3.

\subsubsection{Agreeing vs. non-agreeing verbs}

As discussed in $\$ 2.5$, Archi has a closed list of morphologically simple dynamic verbs which serve as bases for all the verbs in the lexicon. Combined, only about a third of simple and complex verbs agree (simple verbs alone show a different picture, see Chumakina \& Corbett (2015) for details and discussion). The ability of the verb to agree depends entirely on its morphological build and does not depend on either its semantic or syntactic characteristics; the non-agreeing verbs do not make a semantically coherent group, and there are agreeing and non-agreeing verbs among intransitive and transitive (ergative-absolutive) verbs. The examples in (82)-(85) illustrate this with agreeing and non-agreeing verbs of each type. Note, in each case, that (i) the agreeing and non-agreeing verbs belong to the same semantic class and (ii) nothing changes in the structure of the clause whether its predicate is an agreeing or a non-agreeing verb (syntax is blind to the difference).

(82) Intransitive agreeing verb

Ajša da-q $q^{\complement} a$

Aisha II.SG-come.PFV

'Aisha came.'

(83) Intransitive non-agreeing verb

Ajša boq's

Aisha return.PFv

'Aisha returned.'

(84) Transitive agreeing verb

zari lo-bur $\quad$ ir $a<b>u$

1.SG.ERG boy(I)-PL.ABS behind «I/II.PL \make.PFV

'I brought the boys.' 
Transitive non-agreeing verb

$$
\begin{aligned}
& \text { zari lo-bur barhu } \\
& \text { 1SG.ERG boy(I)-PL.ABS look.after.PFV }
\end{aligned}
$$

'Dynamic' verbs with dative subjects all agree, because they are based on several simple dynamic verbs with dative-absolutive alignment (akius 'see', kos 'hear' and $\chi o s$ 'find'). However, stative verbs with dative subjects do not agree. This contrast is illustrated by (86) and (87).

(86) Transitive agreeing (dynamic) verb with a dative subject

$$
\begin{aligned}
& \text { d-ez Ajša da-k:u } \\
& \text { II.SG-1sG.DAT } \\
& \text { 'I saw Aisha } \\
& \text { II.SG-see.PFV }
\end{aligned}
$$

(87) Transitive non-agreeing (stative) verb with a dative subject

d-ez Ajša kł’an

II.SG-1SG.DAT Aisha love

'I love Aisha.'

Recall that the stative-dynamic division between verbs is also morphological (§2.5.1), so, again, it is the morphology, not semantics or syntax, which determines whether the verb agrees or not.

\subsubsection{Agreeing vs. non-agreeing adverbs}

Among 383 adverbs registered in the Archi dictionary (Chumakina et al. 2007a, b) only 13 agree. The full list of agreeing adverbs is presented in (88).

(88) a. allej‘t'>u 'for free'

b. ditra $a$ t' $\rangle$ 'early'

c. horo:kej〈t'>u 'a very long time ago'

d. jellej‘t'>u 'in this way'

e. $k^{\prime}$ 'ellej $\langle t$ '>u 'entirely'

f. mumat:ij〈t'> 'while I am asking you nicely'

g. norsu〈t'>u 'a long time ago'

h. sij〈t'>u 'one (by oneself)'

i. wallit:ej〈t' $\rangle$ 'at the very beginning'

j. žaq $a\left\langle t^{\prime}>u\right.$ 'between themselves'

k. $\check{z} a q^{\S} d i j\left\langle t^{\prime}\right\rangle u$ 'in their way, in their manner' 
l. že $q^{\S} d i j\langle t$ ' $u$ 'in her way, in her manner'

m. žuq $d i j\langle t$ 'su 'in his way, in his manner'

Once again, there is no semantic or phonological homogeneity among these. All agreeing adverbs realize agreement by an infix marking gender-number. There is also nothing in the syntactic behaviour (except, naturally, the ability to agree,) which can distinguish agreeing adverbs from non-agreeing: all of them can be positioned in the right or left periphery of the clause or immediately before the predicate. The examples in (89) and (90) show both types of adverb used in a similar environment.

$$
\begin{aligned}
& \text { Agreeing adverb } \\
& \text { Pat'i dit:a<r>u da-q } q^{\varsigma} a \\
& \text { Pati(II).SG.ABS early〈II.SG> II.SG-come.PFV } \\
& \text { 'Pati came early.' }
\end{aligned}
$$

\section{(90) Non-agreeing adverb}

$$
\begin{aligned}
& \text { Pat'i treši da-q`a } \\
& \text { Pati(II)[SG.ABS] late } \quad \text { II.SG-come.PFV } \\
& \text { 'Pati came late.' }
\end{aligned}
$$

Data of this kind indicates that the agreement potential of adverbs is not determined by their syntactic position (although see $\S 7.4$ for an alternative analysis).

\subsubsection{Agreeing vs. non-agreeing postpositions}

There is only one agreeing postposition in Archi, namely, eq'en 'up to'. It originates from an irregular converb of the verb eq'is 'reach', but has fully grammaticalized into a postposition, whose semantics and syntax are clearly different from that of a converb (see Chumakina \& Brown, to appear, for discussion). The agreeing postposition shares all the syntactic characteristics exhibited by postpositions in Archi, but has the added ability to agree. The examples in (91) and (92) show agreeing and non-agreeing postpositions used in the same position in the clause. In both examples the predicate is a verb of motion.

$$
\begin{aligned}
& \text { Agreeing postposition eq'en 'up to' } \\
& \begin{array}{llll}
\text { to-r } & \text { da-q'a } & \text { masa-k } & \text { e }<\text { r }>q^{\prime} \text { 'en } \\
\text { that-II.SG[ABS] } & \text { II.SG-come.PFV } & \text { magar-LAT } & \text { «II.SG }>\text { up.to }
\end{array}
\end{aligned}
$$

'She went up to the Magar village.' 
Non-agreeing postposition $\chi i r^{\prime}$ 'after'

jamu-t siafal-li-t uq a-li ju-w jemim-me-s $\chi$ ir

that-IV.SG time(IV)-SG.OBL-SUP I.SG.go.PFV-EVID this-I.SG[ABS] that.PL-PL.OBL-DAT after

'At that moment he went after them.' (T26: 73)

The fact that agreement potential is not determined by the (surface) structural position of the postposition indicates that a theoretical account for this difference must make reference to other types of differences between these items.

\subsubsection{Agreeing vs. non-agreeing modifiers}

Nominal modifiers in Archi fall into two distinct groups. Demonstratives (§3.1.1) attributives (§3.1.2) and numerals (§3.2.4) always show agreement, while nominal-adjectives (§4.3.4.1) and non-numeral quantifiers (§4.3.4.2) never do.

\subsubsection{Nominal adjectives}

Archi has a small class of non-agreeing nominal adjectives that have a syntactic distribution that is distinct from that of attributives, and do not inflect for any inflectional categories of their own (Bond \& Chumakina, to appear). A typical example of a nominal adjective is provided in (93), where $o^{\varsigma} r{ }^{\varsigma} S$ 'Russian' is a (noun-like) modifier of a nominal head.

$$
\begin{aligned}
& \text { o'ro`s lo } \\
& \text { Russian child(I)[SG.ABS] } \\
& \text { 'Russian boy' }
\end{aligned}
$$

There are 24 known members of this lexical class. They can be grouped into general semantic classes of ethnicities, as in (94) and properties, as in (95).

(94) Ethnicities
a. aršat:en 'Archi'
f. o'ro's 'Russian'
b. dargin 'Dargi'
g. parang 'French'
c. haman 'Lak'
h. pirsii 'Persian'
d. jat:an 'Avar'
i. Sarab 'Arabic'
е. nuвај 'Nogaj'

(95) Properties
a. a ${ }^{\text {ra }}{ }^{\text {¿̌c' ' }}$ reasonably big'
i. hosol 'ripe'
b. bišin 'weird'
j. kulu 'orphan'
c. buraq' 'bronze'
k. trenne 'female'
d. but'u 'different'
l. maSarul 'mountainous'
e. č'ere 'barren, dry'
m. mektle 'male'
f. čelennin 'privately owned'
n. nak'alaj 'old, ancient, bygone' 

g. dalu 'loony, crazy'
o. wa ${ }^{\text {f }}$ ' 'fat, chubby'
h. hok'o 'small'

While no members of this class ever agree, some members have semantically

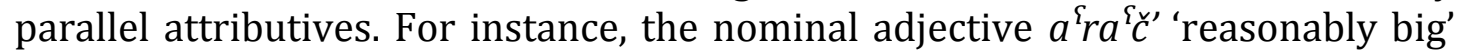
can be contrasted with the attributive $d o^{\delta_{x}}$ :zur 'big, fat'. A closer minimal pair is exemplified by the examples in (96), where the nominal adjective $\hbar k^{\prime}$ ' 'small' is invariant, and the attributive t'it:ut/t'it:ib 'small' agrees with the head it modifies in (97).

(96) a. hok'o lo

small child(IV)[SG.ABS]

'small child'

b. ћok'o lo-bur

small child(IV)-PL.ABS

'small children'

(97)
a. t'i-t:u-t lo
b. t'i-t:-ib lo-bur
small-ATTR-IV.SG child(IV)[SG.ABS]
small-ATTR-PL child(IV)-PL.ABS
'small child'
'small children'

The fact that nominal adjectives do not agree could be considered theoretically problematic if they were analysed as a set of (non-transposed/underived) attributives/adjectives.

\subsubsection{Quantifiers}

A list of non-numeral quantifiers in Archi is provided in Table 4.2. Like nominal adjectives, quantifiers precede the nominal head and do not agree with the noun they modify, as with ho:nu 'all' in (98).

Table 4.2. Quantifiers in Archi

\begin{tabular}{|l|l|}
\hline QUANTIFIER & TRANSLATION \\
\hline čeћ & not at all, not one \\
\hline ho:nu & of any kind, all \\
\hline marči & everybody, everyone \\
\hline na:q'ukan & a lot \\
\hline obš:i & all, whole \\
\hline os para & some \\
\hline
\end{tabular}




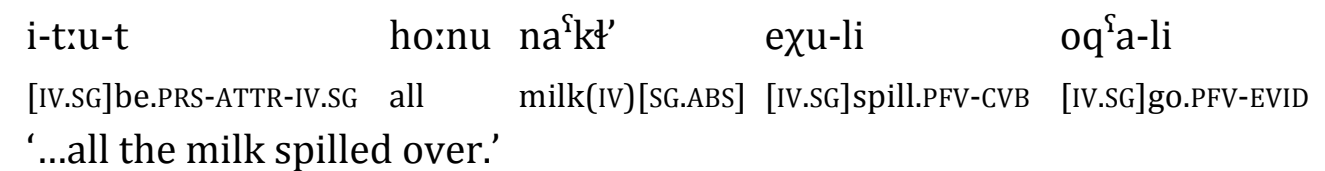

However, quantifiers must always precede nominal adjectives and other attributive modifiers when present in a noun phrase, indicating that they have different distributional properties to adjuncts, as illustrated by the contrast between (99a) and (99b).
$\begin{array}{llll}\text { a. ja-t duxriq } & \text { čeh } & \text { hiba-t:u-t } & \text { adam } \\ \text { this-IV.SG village(IV).SG.OBL.IN } & \text { not.one be.good-ATTR-IV.SG } & \text { person(IV)[SG.ABS] }\end{array}$
i-t'u
[IV.SG]be.PRS-NEG
'In this village there is not one good person.'
b. *ja-t duxriq ${ }^{\varsigma} \quad$ hiba-tuu-t čeћ adam
this-IV.SG village(IV).SG.OBL.IN be.good-ATTR-IV.SG not.one person(IV)[SG.ABS]
i-t'u
[IV.SG] be.PRS-NEG
Intended: 'In this village there is not one good person.'

Quantifiers cannot be preceded by other modifiers, as demonstrated by the ungrammatical example in (100). This is another indication that quantifiers occur in a different syntactic position to other modifiers.
(100) *ja-t čeh adam
this-II.SG not.one person(IV)[SG.ABS]
Intended: 'this person with no qualities'

These properties suggest that this set of quantifiers should be given a distinct analysis in any model accounting for the agreement potential of different lexical items.

\subsection{Conclusion}

We have argued that within the Archi agreement system different types of 'competing controllers' are encountered. These include constructions where grammatical and semantic properties of the absolutive argument of a clause are in competition to control the featural specification of a clausal target ( $\$ 4.2)$ and biabsolutive constructions in which the subject and the object of the clause are both absolutive - and may each control a subset of the possible agreement relations within a (mono-)clausal domain (§4.3). Any viable model of syntax must be able to account for this type of non-canonical variability using the mechanisms that are already available in the theoretical architecture, or by developing new ways to explain the restrictions on what is encountered. We 
have also shown that, despite the pervasiveness of agreement in Archi, not every lexical item has the potential to agree $(\S 4.4)$. This fact suggests that adequate models must either account for variability across targets with respect to their individual lexical characteristics, or devise arguments to establish classes based on syntactic or semantic characteristics of agreeing and non-agreeing targets. 